\title{
Following the Money: Fenian Bonds, Diasporic Nationalism, and Distant Revolutions in the Mid-Nineteenth-Century United States
}

The United States was home to a market in distant revolutions in the middle decades of the nineteenth century. ${ }^{1}$ Between the late 1830 s and the end of the 1860 s, American citizens could invest in a range of bonds produced by nationalist and secessionist movements. Each required a leap of faith to imagine a geopolitical state of affairs that was at odds with immediate reality, sometimes radically so. This article analyses one case - that of mid-century Irish-American nationalism - to assess participation in this marketplace and the means by which those standing outside Lincoln's 'family of nations' sought to work their way into its embrace. ${ }^{2}$ It builds outwards from a single, tangible source - the bonds of the Irish Republic, yet to be established - to offer a material history of nationalist aspiration, failure and redemption. In addition to these bonds, this article draws on newspaper reports, the correspondence of British diplomats, letters between Irish-American nationalists, and a hitherto unused Fenian Brotherhood bond ledger book to make three claims. ${ }^{3}$

The first is that bond issues by revolutionary movements demonstrate that debt was an important means of building and sustaining communities that could contest existing state relations. Historians have emphasised the connection between the growth of debt markets and the evolution of the modern nation-state but they have not been as attentive to the social and emotional (as well as financial) work that debt does for aspirant nations. ${ }^{4}$ The Fenian

\footnotetext{
${ }^{1}$ I have borrowed the phrase 'distant revolutions' from Timothy Mason Roberts, Distant Revolutions: 1848 and the Challenge to American Exceptionalism (Charlottesville, 2009).

2 Abraham Lincoln, 'Proclamation of a Day of Prayer', 7 Jul. 1864, Collected Works of Abraham Lincoln accessed online at http://quod.lib.umich.edu/l/lincoln/ Accessed 16 Dec. 2015.

${ }^{3}$ Ledger of Accounts, 1865-1867, Fenian Brotherhood papers, American Catholic History Research Center and University Archives, The Catholic University of America [hereafter FB papers], box 3, folder 1.

${ }^{4}$ See, for instance, John Brewer, The Sinews of Power: War and the English State, 1688-1783 (London, 1989); Niall Ferguson, The Cash Nexus: Money and Power in the Modern World 1700-2000 (London, 2001), 107-194; and, in a U.S. context, Jay Sexton, Debtor Diplomacy: Finance and American Foreign Relations in the Civil War Era, 1837-1873 (Oxford, 2002).
} 
Brotherhood was a diasporic community performing an important aspect of the life of the modern nation-state, apparently embracing the cold and neutral logic of the capitalist bond market of the nineteenth century but with an extra-economic goal: in addition to raising funds they made a geopolitical claim on behalf of a nationally-defined social group. Bonds acted as a form of 'special money': financial instruments marked by social and cultural assumptions that transcend their nominal monetary value. ${ }^{5}$ Fenian bonds fit this model although, as will be seen, their ultimate redemption suggests that what might be special money for one generation can devolve into its immediate financial form in the next. ${ }^{6}$

Second, this article argues that bonds formed part of a historically specific 'repertoire of contention', to use historical sociologist Charles Tilly's phrase. ${ }^{7}$ Historians have investigated various individual cases of bonds being used to generate funds, but none have explored this commonality in the use of bonds among various, disparate groups. Its recurrence suggests an accepted model for generating external support for national selfdetermination. The bond, in its social, financial and political aspects, was something that such groups could reach for at this particular moment in time and in this particular place. Why? This article contends that a recent and enduring culture of free banking in the United States, in which anyone could print promissory notes; largely unregulated bond markets; a long history of apparent sympathy with republican revolutions outside the United States; a drive to consolidate domestic sentiment in support of these distant revolutions; and aggressive if

\footnotetext{
5 The phrase is Viviana A. Zelizer's. from her 'The Social Meaning of Money: "Special Monies"', American Journal of Sociology, xcv (1989).

${ }^{6}$ For a similar historical trajectory, see Steven C. Topik, 'When Mexico Had the Blues: a Transatlantic Tale of Bonds, Bankers, and Nationalists, 1862-1910, American Historical Review, cv (2000). On the mutability of debt and its financialisation, see David Graeber, Debt: the First 5,000 Years (Brooklyn, 2011).

${ }^{7}$ Charles Tilly, From Mobilization to Revolution (Reading, Mass., 1978); Sidney Tarrow, 'Modular Collective Action and the Rise of the Social Movement: Why the French Revolution Was Not Enough', Politics \& Society, xxi (1993); and Sarah A. Soule, 'Diffusion Processes Within and Across Movements', in David A. Snow, Sarah A. Soule and Hanspeter Kriesi (eds.), The Blackwell Companion to Social Movements (Malden, Mass., 2007), esp. 299-301. I came to this concept via Maartje Janse, "Holland as a Little England”? British Anti-Slaery Missionaries and Continental Abolitionist Movements in the Mid Nineteenth Century', Past \& Present ccxxix (2015).
} 
contested public interest in American expansion all worked to render this kind of investment an attractive tool at this moment in time. These are contingent reasons, specific to the United States. More broadly this article concurs with those historians who have seen bonds, debt, and banknotes as central to nation-state-building. This was, after all, a period in which the issuance of paper notes was intrinsically bound up with the claims of nation-states to modernity and legitimacy. Historians have generally assessed this in the context of whose claim to nationhood was rooted in their occupation of the territory they claimed. This article suggests that this logic might also be employed by those who wished to assert their legitimacy and their modernity in a diasporic context. I argue that the marketplace in nationalist and secessionist bonds suggests that debt can reflect and constitute a connection between citizen and nation diasporically, even where that nation-state is only speculative.

Third, these bonds offer us a way of grounding and making tangible the intellectual and ideological connections proposed by historians and historical geographers who have done such fine work in transnationalising our understanding of nationalism in the mid-nineteenth century. ${ }^{8}$ One implication of this literature is that we can better connect nation, state and empire formation in the United States with the percolation of nationalist thought elsewhere, though we still know more about ideas than we do about processes. This article addresses this imbalance by following a single object - the Fenian bond - through its commission, purchase

\footnotetext{
${ }^{8}$ In general, see C. A. Bayly, The Birth of the Modern World, 1780-1914 (Oxford, 2004), 199-243; A. G. Hopkins (ed.), Globalization in World History (London, 2002); and Jürgen Osterhammel, The Transformation of the World: a Global History of the Nineteenth Century (Princeton, 2014), 392-468. On the U.S. in particular, see David T. Gleeson and Simon Lewis (eds.) The Civil War as Global Conflict (Columbia, SC, 2014); Don H. Doyle, The Cause of All Nations: an International History of the American Civil War (New York, 2014); Various, 'Interchange: Nationalism and Internationalism in the Era of the Civil War', Journal of American History, xcviii (2011); Richard Carwardine and Jay Sexton (eds.), The Global Lincoln (New York, 2011); Thomas Bender, A Nation Among Nations: America's Place in World History (New York, 2006), 116-181; Roberts, Distant Revolutions; Paul Quigley, Shifting Grounds: Nationalism and the American South, 1848-1865 (New York, 2012); W. Caleb McDaniel and Bethany L. Johnson, 'New Approaches to Internationalizing the History of the Civil War Era', The Journal of the Civil War Era, ii (2012); and Matthew Karp, This Vast Southern Empire: Slaveholders at the Helm of American Foreign Policy (Cambridge, Mass., 2017). In an Irish context see a special issue of Éire-Ireland, 'Beyond the Nation: Transnational Ireland', li (2016), and Niall Whelehan (ed.), Transnational Perspective on Modern Irish History (New York, 2015).
} 
and redemption. It allows us to move away from more abstract discussions of liberalism, nationalism and imperialism, towards a bottom-up understanding of transnational community and revolutionary sympathy in this period. As anthropologist Daniel Miller has written (in a very different context): 'material culture is often the concrete means by which the contradictions held within general concepts such as the domestic or the global are resolved in everyday life.' Fenian bonds sold in small denominations in working-class neighborhoods exemplify this. ${ }^{9}$ Neither the bonds themselves nor the bondholders might ever again see Ireland, but these objects allowed people with little capital participation in a form of everyday diasporic transnationalism, as individuals could engage in transnational community-building in their immediate locality. ${ }^{10}$ The sample size that this article discusses is small, but it allows us to pair a horizontal analysis - this is happening in a variety of places over a period of decades - with a vertical one: here are the detailed mechanics of revolutionary bond issuance in the urban United States in the middle of the nineteenth-century. With this, we can gain some modest but significant insight into the kinds of people involved in their sale and purchase, the context in which such people operated, and the political, financial and diplomatic implications of their actions.

This article begins with the promise inscribed on the bonds issued by the Fenian Brotherhood in New York City as that organisation, the American corollary of the Irish Republican Brotherhood (I.R.B.), sought to raise money to fund revolution in Ireland in the mid-1860s. The promise was that the sum subscribed by bondholders would be 'redeemable Six Months after the acknowledgment of the Independence of the Irish Nation with interest from the date hereof inclusive at Six per cent per annum payable on presentation of this bond

\footnotetext{
${ }^{9}$ Daniel Miller, 'Why Some Things Matter', in Daniel Miller (ed.), Material Culture: Why Some Things Matter (Chicago, 1998), 19.

${ }^{10}$ Rogers Brubaker et al., Nationalist Politics and Everyday Ethnicity in a Transylvanian Town (Princeton, 2008); Geneviève Zubrzycki (ed.), National Matters: Materiality, Culture and Nationalism (Stanford, 2017).
} 
at the Treasury of the Irish Republic.' ${ }^{11}$ This article then considers the broader context of bond issuance by revolutionary, secessionist and nationalist non-state actors, and examines their impact on Anglo-American diplomacy in the years following the Civil War. It makes a methodological claim: historians should bring to the history of bonds and similar financial instruments the same sensitivity and insight that they have shown when theorising the production, iconography of money and its attendant social and cultural contexts. ${ }^{12}$ Finally, this article concludes with the discharged pledges of a dead generation, as the provisional Irish government exchanged outstanding Fenian bonds for bonds issued in the name of the revolutionary Irish state. Redemption came a decade later, and by 1937 the Free State had paid its debt to its bondholders. Far from being the junk bonds assumed by the Fenian Brotherhood's contemporaries, Fenian bonds proved a surprisingly durable investment.

Historians have done little to analyse bonds such as these, though they have sketched a growing public familiarity with wartime and railroad securities from the early $1860 \mathrm{~s}$ onwards. ${ }^{13}$ The bonds and treasury notes of the Texan Republic, issued in the late 1830s and early 1840s, have attracted some attention but Anglophone historians of bond issues by revolutionary organisations have generally focused on the London market and on the sovereign debt of newly-established nations rather than the issue of promissory notes by revolutionary movements prior to their recognition. Latin American bonds, in particular, have drawn the attention of economic historians, who have investigated the role of mediating banks, British diplomatic recognition, the development of sovereign debt, and the causes and

\footnotetext{
11 Ten dollar bond, FB papers, box 3, folder 5 .

${ }^{12}$ Dan Lainer-Vos does exactly this for the Irish bond drive of the late 1910s, in comparison with Zionist bond issues of the 1940s and 1950s. For more on the former, see below. Lainer-Vos seems unaware of the earlier Fenian bond drive. Dan Lainer-Vos, Sinews of the Nation: Constructing Irish and Zionist Bonds in the United States (Cambridge, 2013). For a great example of the sensitive theorisation of the production and iconography of banknotes, see Emily Gilbert, “'Ornamenting the Façade of Hell”: Iconographies of $19^{\text {th }}$-century Canadian Paper Money', Society and Space xvi (1998).

${ }^{13}$ See, for instance, David K. Thomson, "Like a Cord Through the Whole Country": Union Bonds and Financial Mobilization for Victory', Journal of the Civil War Era, vi (2016); and Richard White, Railroaded: the Transcontinentals and the Making of Modern America (New York, 2011), 10-11, 15-16.
} 
implications of debt crises. ${ }^{14}$ These issues generally came with the imprimatur of a trusted banking house. ${ }^{15}$ In the United States, by contrast, such issues were generally marketed directly to the public via bond agents. Whilst historians of U.S. foreign relations have produced rich studies of the Confederacy's wartime hunt for finance in Europe, they have said little about the mass of reciprocal efforts, as secessionist, anti-imperial and nationalist groups sought to secure funds in the United States itself. ${ }^{16}$ In part this is because of the fragmented source material and the difficulty of reconstructing this underworld of American foreign relations. The records of the Fenian Brotherhood offer a novel opportunity to reconstruct this underworld.

Irish nationalists founded the Fenian Brotherhood in New York City in 1858 as an organisation dedicated to forcibly ending British rule in Ireland. It was intended to be the auxiliary association to the Irish Republican Brotherhood, supplying that organisation with money, men, and arms. Many early members, including the Brotherhood's first president, John O’Mahony, had taken part in the failed Irish rebellion of 1848, and were convinced of the need for a more robust, disciplined organisation to sustain their efforts for Irish home rule. ${ }^{17}$ The Fenian Brotherhood made the decision to issue bonds at its national convention at

\footnotetext{
${ }^{14}$ Marc Flandreau and Juan H. Flores, 'Bonds and Brands: Foundations of Sovereign Debt Markets, 18201830', Journal of Economic History, lxix (2009); Giorgio Fodor, 'The Boom That Never Was? Latin American Loans in London', paper presented at the 'Crisis: From the Real Economy to the Financial System' conference, Venice, 17-18 Nov. 2000; and Frank Griffith Dawson, The First Latin American Debt Crisis: the City of London and the 1822-25 Loan Bubble (New Haven, Conn., 1990), esp. 22-46.

15 Jacob Viner, 'Political Aspects of International Finance', The Journal of Business of the University of Chicago, i (1928), 155-157; Flandreau and Flores, 'Bonds and Brands'.

${ }^{16}$ Sexton, Debtor Diplomacy, 134-189; Marc D. Weidenmier, 'The Market for Confederate Cotton Bonds', Explorations in Economic History, xxxvi (2000); Douglas B. Ball, Financial Failure and Confederate Defeat (Urbana and Chicago, 1991), 206-248.

${ }^{17}$ For a brief overview of the Brotherhood see David Sim, 'Fenian Brotherhood', Edward J. Blum (ed.), America in the World, 1776 to the Present: a Supplement to the Dictionary of American History (Farmington Hills, Mich., 2016), i, 357-358.
} 
Cincinnati in January 1865. In his opening address O’Mahony stressed the importance of shaping what was then 'a military organization,' a product of recruitment drives in Union and Confederate camps during the Civil War, into a 'civic and self-governing body... no longer dependent upon... any small number of individuals,' but comparable with 'any chartered corporation in the country. ${ }^{18}$ The bond issue was intended to complement the dues system already in place, as individuals would pay ten cents per week at meetings of their local Brotherhood 'circle. ${ }^{, 19}$ Bonds were novel: earlier efforts to secure Irish home rule had rested on ad hoc contributions or, in the case of the 1840s campaign to repeal the Act of Union between Britain and Ireland, small, regular donations known as 'Repeal Rent.' ${ }^{20}$ By contrast, bonds were a more sophisticated and administratively complex instrument with which to raise money. Regulations about their issue were written into the Brotherhood's constitution as part of the effort to establish 'a never-failing base of supplies' for revolutionary activity in Ireland. ${ }^{21}$ The audited ledger book mined below is a product of this emphasis on professionalism and transparency.

With its public sessions and reportedly large audiences, the Cincinnati convention demonstrated the importance of the performance of diasporic nationalism for Ireland's claim to a place among the powers of the earth. ${ }^{22}$ The implementation of a constitution; the election of officials; the establishment of a small central bureaucracy to maintain the organisation between conventions; the issuing of bonds with appropriate oversight; the commitment in

\footnotetext{
18 John O'Mahony's address, Proceedings of the Second National Congress of the Fenian Brotherhood, Held in Cincinnati, Ohio, January, 1865 (Philadelphia, 1865), 6.

19 'Third Day's Session', in ibid., 29-30; William D’Arcy, The Fenian Movement in the United States 18581886 (New York, 1971), 180.

${ }^{20}$ John Belchem, 'Nationalism, Republicanism and Exile: Irish Emigrants and the Revolutions of 1848', Past \& Present, cxlvi (1995), 110-118. On the transatlantic dimensions of the Repeal movement, including its fundraising, see Angela F. Murphy, American Slavery, Irish Freedom: Abolition, Immigrant Citizenship, and the Transatlantic Movement for Irish Repeal (Baton Rouge, 2010).

21 'Constitution of the Fenian Brotherhood', in Second National Congress, 36-37; 'First Organized Session', in same, 13.

22 'The Fenian Convention', Daily Ohio Statesman (Columbus, Oh), 20 Jan. 1865, 3.
} 
January 1865 to endure as 'a fixed and permanent institution in America,' and the assertion that the Irish people 'constitute one of the distinct nationalities of the earth, and as such [are] justly entitled to all the rights of self-government' all pointed to a desire to build 'a durable political entity rather than a crisis-driven, perishable movement. ${ }^{23}$

John O’Mahony may have envisaged a more professional Brotherhood but Fenian leaders on both sides of the Atlantic were aware that the process of raising and remitting money was problematicremained haphazard and uncertain through 1865 . The Fenians relied on individual bankers' drafts, issued by Belmont \& Co. in New York City and drawn on N. M. Rothschild \& Sons in London. Five of these, amounting to just under $\$ 27,000$, were intercepted by the British government in late summer $1865 .^{24}$ In November 1865 , the IRB appointed John Mitchel, arguably the most famous of the post-1848 Irish exiles, as the Brotherhood's financial agent in Paris, responsible for receiving money from the United States. ${ }^{25}$ Conscious of being watched by British spies, Mitchel instituted a more meticulous financial regime, sending regular information on remittances and moving bank on occasion (though the Fenians continued to send money via Rothschild \& Sons. $)^{26}$

Simultaneously, the Brotherhood pushed hard to raise a large sum of money after it issued a 'final call' for funds that August. ${ }^{27} \mathrm{~A}$ key component of this fund drive was the Fenian bond, which was a diasporic initiative. By October 1865 newspapers throughout the

\footnotetext{
23 ibid., 55-56.

24 The bank's refusal to offer the Fenian Brotherhood a refund for those intercepted bonds resulted in a lengthy court battle beginning in the summer of 1869 and, in the early 1880s, a libel suit. 'The Trial of John Devoy', New York Times, 25 Nov. 1882. For remittances to Joseph Denieffe and William G. Halpin, see remittance notice of 15 Jul. 1865; for those to John O'Leary see notices of 19 Aug., 23 Aug., 2 Sept., 9 Sept., 13 Sept., and 20 Sept. 1865, all in 'Agents' Correspondence: August Belmont \& Co.', XI/62/13B, The London Banking House: American Department, The Rothschild Archive London. Privately, Belmont thought the Fenian Brotherhood a "foolish movement", August Belmont \& Co. to N. M. Rothschild \& Sons, 12 Dec 1865, in same. ${ }^{25}$ O’Mahony to Mitchel, 10 Nov. 1865, in FB papers, box 1, folder 8. On Mitchel's place as a central figure in mid-century Irish-American nationalism, see Bryan P. McGovern, John Mitchel: Irish Nationalist, Southern Secessionist (Knoxville, 2009).

${ }^{26}$ Mitchel to O'Mahony, 10 Mar. 1866, 7 Apr. 1866, and 10 Apr. 1866, all FB papers, box 1, folder 9.

${ }^{27}$ Patrick Steward and Bryan McGovern, The Fenians: Irish Rebellion in the North Atlantic World, $1858-1876$ (Knoxville, 2013), 81.
} 
United States were reporting that the Brotherhood had commissioned the New York-based Continental Bank Note Company to produce a batch of engraved bonds for public sale.

However, before these bonds reached the American public the Fenian Brotherhood split into two factions. William Roberts, recently elected president of the new Fenian Senate, led the impeachment of O'Mahony for signing his own name on these bonds, in breach of the Brotherhood's constitution. (The Brotherhood's treasurer had resigned before he could endorse the bonds; O’Mahony claimed that this left him with no choice but to sign his own name instead. $)^{28}$ More generally, O’Mahony's lack of militancy and the lack of a militant response to a British clampdown on the I.R.B. in September 1865 and dissatisfaction with O’Mahony's uninspiring public performances fed discontent with his leadership. ${ }^{29}$

Beginning in late January 1866 and running through at least November of that year, the O'Mahony faction issued bonds in denominations of five, ten, twenty, fifty, one hundred, and five hundred dollars. These denominations suggest a desire to build a broad base of support amongst people with limited cash to spare. Though one rogue bond agent claimed that the bonds would ultimately be redeemed in gold - a potentially important consideration for anyone looking to invest for financial return - it is hard to know whether this reflected Fenian policy absent any further substantiation. ${ }^{30}$ At the same time, Roberts' rival faction also issued bonds, signed by Michael Scanlan, a militant Fenian (and candy company executive) from Chicago. ${ }^{31}$ The decision to commission the Continental Bank Note Company

\footnotetext{
${ }^{28}$ Ibid., 91; D’Arcy, Fenian Movement, 103.

${ }^{29}$ Steward and McGovern, Fenians, 86-88.

30 'Fenianism', New York Herald, 2 Dec. 1865, 1. The bond agent in question was one E. Brown, listed as head of the 'St Lawrence O'Toole Circle, New York City', Ledger of Accounts, 1865-1867, FB papers, box 3, folder 1,207 . The circle raised $\$ 575$ in bond sales.

${ }^{31}$ Historians have not been clear about the division of the funds raised by the sale of bonds; it seems very unlikely that the Brotherhood's two factions would have shared the revenue generated. This uncertainty is present even in Robert Alan Doan's 'Green Gold to the Emerald Shores: Irish Immigration to the United States and Transatlantic Monetary Aid, 1854-1923' (unpubld PhD dissertation, Temple University, 1999), an otherwise excellent study of long-term Irish republican fundraising. The ledger which this article analyses appears to have belonged to the O'Mahony faction of the Brotherhood. This is suggested by an interleaved cutting of a letter from Patrick A. Collins in which he defended his bookkeeping practices: Collins had served as
} 
indicated a seriousness of purpose on the part of the Brotherhood. The Company was known for its use of sophisticated technology and, alongside two other companies, won the contract to produce U.S. bank notes under the terms of the 1863 National Banking Act. ${ }^{32}$ Between July 1863 and January 1870 the federal government paid the Company more than $\$ 500,000$ banknotes and bonds for the nation; they also produced bank notes for Japan's Meiji government. ${ }^{33}$ For the Fenian project the Company made designs from scratch rather than using a composite of older bank note plates - something that would have raised the cost to the Brotherhood but offered greater guarantees against forgery. ${ }^{34}$

The appearance of these coincided with a period of intense debate over the nature of American banknotes, and in a context in which Americans were in general more familiar with bonds as commonplace financial instruments. As numerous historians have noted, the money supply in the antebellum United States was 'consistently promiscuous:' anyone with a small amount of cash and sufficient persuasive power might issue bank notes and coin money, and foreign specie circulated freely. ${ }^{35}$ Churches, insurance agencies, agricultural societies and individual merchants, amongst others, issued promissory notes that functioned as ready

\footnotetext{
a subscription agent for the Brotherhood and was a supporter of O'Mahony after the split. Likewise, James McGrath appears in the ledger as a bond agent in St. Louis, Missouri, and he was later an O'Mahony appointee to the Central Council of his faction of the Brotherhood. Patrick Collins to the Editors of the Irish People in Ledger of Accounts, 1865-1867, FB papers, box 3, folder 1, n.p.; 'James McGrath' in same, 55; D'Arcy, Fenian Movement, 107, 112, 126; Mícheàl De Búrca, Life and Poems of Michael Scanlan, The Fenian Poet (Kilmallock, 1969), 3.

32 Stephen Mihm, A Nation of Counterfeiters: Capitalists, Con Men, and the Making of the United States (Cambridge, Mass., 2007), 337-338.

${ }^{33}$ Report of the Secretary of the Treasury on money paid to bank note companies, House Executive Document No. 188, 14 Mar. 1870, $41^{\text {st }}$ Congress, ${ }^{\text {nd }}$ Session, United States Congressional Serial Set (Washington, D.C., 1817-), 2; Eric Helleiner, The Making of National Money: Territorial Currencies in Historical Perspective (Ithaca, NY, 2003), 103. On the Meiji reforms of Japan's banking system, including the introduction of new banknotes, see Masato Shizume and Masayoshi Tsurumi, 'Modernizing the Financial System in Japan during the 19t Century: National Banks in Japan in the Context of Free Banking', Working Papers 1607, Waseda Institute of Political Economy, Waseda University (2016).

34 'The Irish Bonds', New York Herald, 26 Oct. 1865, 4. The Company was especially alert to the dangers of counterfeiting because one of its founders was a notorious former forger who had published an exposé of the industry in 1852. See Mihm, Nation of Counterfeiters, 260-277, 338, 350.

${ }^{35}$ Michael O’Malley, Face Value: the Entwined Histories of Money and Race in America (Chicago, 2012$), 59$.
} 
cash. ${ }^{36}$ In this context, such bonds were just one more form of financial obligation, as valuable as people collectively decided that they were. The challenges of financing the Civil War prompted both an intense debate over paper money, and a massive expansion and democratisation of the domestic bond market. The Union issued more than $\$ 2.2 \mathrm{bn}$ worth of securities to as many as three million people, private firms conducted successful public promotion campaigns to encourage people to invest in them, and bond agents travelled to 'every nook and corner' of the northern states. ${ }^{37}$ The circulation of greenbacks and the democratic messaging that accompanied bond drives meant that the American public in 1865 was far more conversant with such notes than it had been at the beginning of the war when, one newspaper commented, 'a United States Loan has never been heard of far outside of the larger cities. ${ }^{38}$ And, though formal financial institutions like the New York Stock Exchange expanded significantly, this remained a largely informal, interpersonal world, reliant on local bond agents and civic sensibility.

It is hard to know how much cash the 'greenbacks of Patrick and Bridget' brought to the Brotherhood. ${ }^{39}$ Robert Doan's history of American financing of Irish nationalism suggests that bond sales were disappointing, with many Fenian circles failing to sell any bonds at all. ${ }^{40}$ His suggestion that only $\$ 4,530$ worth of bonds were sold is too low, however, because it rests only on the report of the Roberts faction and only covers those bonds bought directly

\footnotetext{
${ }^{36}$ Ibid., 44-82; Mihm, Nation of Counterfeiters, 1-19; John Kenneth Galbraith, Money: Whence It Came, Where It Went (Princeton, 2017 repr.), 97-103.

${ }^{37}$ O’Malley, Face Value, 83-123; Thomson, 'Union Bonds'. The smallest denomination of Union bond was \$50. On bond markets more generally during this period, see Richard Franklin Bensel, Yankee Leviathan: the Origins of Central State Authority in America, 1859-1977 (Cambridge, 1990), 249-262; Lance Davis and Robert Cull, 'International Capital Movements, Domestic Capital Markets, and American Economic Growth, 18201914', in Stanley L. Engerman and Robert E. Gallman (eds.), The Cambridge Economic History of the United States (Cambridge, 2000), 771-784; and Melinda Lawson, Patriot Fires: Forging a New American Nationalism in the Civil War North (Lawrence, KS, 2002), 41.

${ }^{38}$ Ibid., 43

39 'Difficulty Among the Fenians', Evening Star (Washington D.C.), 9 Dec. 1865, p1.

${ }^{40}$ Doan, 'Green Gold', 65.
} 
from the central organisation and its agents. ${ }^{41}$ According the O'Mahony faction's ledger book, bond sales brought in $\$ 60,775.01$ between late January 1866 and the end of June 1867 . That constituted about a fifth of the total amount of bonds issued. ${ }^{42}$ The New York Times, always sniffy about the Brotherhood and unlikely to oversell its achievements, reported that at least $\$ 100,000$ worth of bonds had been sold by mid-November $1866 .{ }^{43}$ Some circles were more successful than others, of course. Brooklyn's Tara Circle cleared almost all of the $\$ 1250$ worth of bonds to which they had subscribed. Manhattan's Red Hand Circle did even better, oversubscribing by more than $80 \%$, taking just under $\$ 3000$ in the course of $1866 .{ }^{44}$ Others were less successful. The three southern bond agents represented in the ledger failed to sell a single bond; one, Patrick Condon, claimed that 'the fate of the Confederate bonds throws a damper on the sale of ours. ${ }^{, 45}$

Such pessimism may have been justified - the following month a congressional committee reported a bill that prohibited payment of Confederate debt - but Condon hinted at a significant comparative phenomenon. ${ }^{46}$ As he suggested, the Fenian Brotherhood was not the only organisation issuing speculative bonds in this period. As bonds issued in the course of insurrection against another power, their closest contemporary comparison were the bonds issued by the Confederacy in March 1863. As historians have detailed, these were 'sold

\footnotetext{
${ }^{41}$ Ibid., 65; D'Arcy, Fenian Movement, 240. The Roberts' faction's original report is P. W. Dunne's 'Abstract of Report of Finance Committee' accessed via the Villanova University Digital Library (hereafter VUDL) at http://digital.library.villanova.edu/Item/vudl:248000. Accessed 24 Sep. 2015. Dunne's report covered the period 8 December 1865 to 31 August 1866 . He noted that $\$ 560,000$ worth of bonds were unaccounted for, out of an issue of $\$ 1,500,000$.

${ }^{42} \$ 310,265$ worth of bonds were issued, giving an uptake of $19.6 \%$. Ledger of Accounts, 1865-1867, FB papers, box 3, folder 1 .

43 'The Fenian Bonds', New York Times, 12 Nov. 1866, 1.

44 'Tara Circle', Ledger of Accounts, 1865-1867, FB papers, box 3, folder 1, 245; 'Red Hand Circle', ibid., 232.

45 'Patrick Condon', 'Major Touhy', and 'John Lawler', all ibid., 62, 63, 143; Patrick Condon to P. J. Downing, 31 Mar 1866, FB papers, box 1, folder 9. By 1869, Condon had changed his mind. He was then working as an informant for the British government and denied ever having had bonds for sale. See The Fenian Conspiracy: Report of the Trials of Thomas Burke and Others (Dublin, 1869), 186.

${ }^{46}$ Eric Foner, Reconstruction: America's Unfinished Revolution, 1863-1877 (New York, 2002), 253; William A. Blair, With Malice Toward Some: Treason and Loyalty in the Civil War Era (Chapel Hill, 2014), 286-293.
} 
primarily in England,' 'denominated in sterling, paid 7\% interest per year,' came in denominations of $£ 1000, £ 500, £ 200$ and $£ 100$, and 'could be converted into cotton on demand ${ }^{47}$ Despite the poor credit record of a number of southern states, the Confederacy had a number of obvious advantages that the Fenian Brotherhood did not. ${ }^{48}$ It established a system of domestic taxation, however averse some Confederates were to enforcing it, and throughout the war years the Confederacy serviced the bonds, making interest payments as they came due. ${ }^{49}$ Unlike the Confederacy, the Fenian Brotherhood's republic was purely speculative, though the Brotherhood's opulent headquarters on Union Square in Manhattan did house a treasury office, 'the same as one would find in a well[-]regulated financial establishment anywhere,' including a bureau dedicated to 'preparing and stamping the Fenian bonds. ${ }^{50}$ There was, however, no commodity underpinning the value of Fenian bonds. By contrast, foreign investors in Confederate securities could opt to convert their debt into cotton if they were prepared to run the Union blockade. ${ }^{51}$

Bonds issued by republican forces during the French intervention in Mexico provided a further comparison for contemporaries. ${ }^{52}$ Needing funds to fight French imperial forces, republican agents worked to sell the $\$ 60,000,000$ worth of bonds issued by the Mexican government in August $1865 .{ }^{53}$ These bonds offered the same six per cent interest but, unlike the Fenian bonds, they were explicitly backed by earmarked taxes plus tariff revenue. There

\footnotetext{
${ }^{47}$ Marc D. Weidenmier, 'Gunboats, Reputation, and Sovereign Repayment: Lessons from the Southern Confederacy,' Journal of International Economics, 1xvi (2005), 408, 412; Weidenmier, 'The Market for Confederate Cotton Bonds', Explorations in Economic History, xxxvi (2000), 78.

${ }^{48}$ On the default of southern states during the 1840s see Sexton, Debtor Diplomacy, 22-53; Weidenmier, 'Southern Confederacy', 410-411.

49 James M. McPherson, Battle Cry of Freedom: the American Civil War (London, 1990), 437-438;

Weidenmier, 'Southern Confederacy', 407-422.

50 'Fenianism', New York Herald, 2 Dec. 1865, 1; Steward and McGovern, Fenians, 88-89.

${ }^{51}$ Sexton, Debtor Diplomacy, 157-174.

52 No title, Wheeling Daily Intelligencer, 15 Dec. 1865, 2.

53 John Mason Hart, Empire and Revolution: the Americans in Mexico Since the Civil War (Berkeley, 2002); Robert W. Frazer, 'The Ochoa Bond Negotiations, 1865-1867', Pacific Historical Review, xi (1942), 398-399. See also Patrick J. Kelly, 'The North American Crisis of the 1860s', Journal of the Civil War Era, ii (2012).
} 
also appears to have been a secondary market for Mexican bonds, as for those of the Confederacy. By contrast, there is little to suggest that Fenian bonds circulated beyond their immediate purchasers and, we can assume, they were backed only by the faith that a republican Ireland would be materially better off - and able to fund its debt with ease - once the burden of British taxation had been lifted. ${ }^{54}$

As this suggests, the Fenian Brotherhood was not alone in seeing bonds as a valuable revolutionary tool. The middle decades of the nineteenth century saw a proliferation of investment opportunities for individuals who were keen to support nationalist and secessionist movements. As such, we should think of the bond as being part of a repertoire of contention: it was a tool that those seeking revolutionary change might reach for in order to disrupt the existing international order, as well as being a financial investment. From late spring 1838, an American investor could purchase the red-backs and bonds of the Texan Republic, the values of which fluctuated wildly with rumours of annexation and a bondholder bailout. ${ }^{55}$ Texas annexation may not have been a sure bet, but it was a less risky investment than the bonds issued by William Walker for his Nicaraguan filibustering projects in the late 1850 s, the face of which indicated Walker's intention to 'unit[e] Central America's five

\footnotetext{
${ }^{54}$ A later generation of Irish nationalists launched their own Bond Drive in 1919 (see below) and made this case. The idea that Britain impoverished Ireland through taxation was common in contemporary literature. See De Valera quoted in Patricia Lavelle, James O'Mara, a Staunch Sinn-Feiner, 1873-1948 (Dublin, 1961 ), 149. 'Dull on the Stock Exchange', New York Times, 27 Jun. 1903, 9, hinted at a secondary market, noting that on 'the dullest day of the year... brokers... bid up [Fenian Bonds] from way below par to 102.' I have been unable to find any additional substantiation for this claim.

${ }^{55}$ Congress agreed to pay the principal and interest on Texan bonds in February 1855. Richard C. Burdekin, 'Bondholder Gains from the Annexation of Texas and Implications of the U.S. Bailout', Explorations in Economic History, xliii (2006); Gary M. Pecquet and Clifford F. Thies, 'Texas Treasury Notes and Market Manipulation, 1837-1842', Explorations in Economic History, xliv (2007).
} 
republics under his rule. ${ }^{56}$ Walker managed to sell some of these bonds to investors in New

Orleans and was successful in using them as a down payment for arms ${ }^{57}$ From 1850 onwards speculators could invest in Narciso Lopez's Cuban filibustering missions, though

filibustering remained such a risky venture that they generally traded at about ten per cent of their face value. ${ }^{58}$ Those whose commitment outlasted the U.S. Civil War could again invest in Cuban futures in the late 1860s [Image 1]. These were taken up 'by the Cubans in New York, at from about 23 to 35 cents on the dollar,' according to one of the city's newspapers. ${ }^{59}$

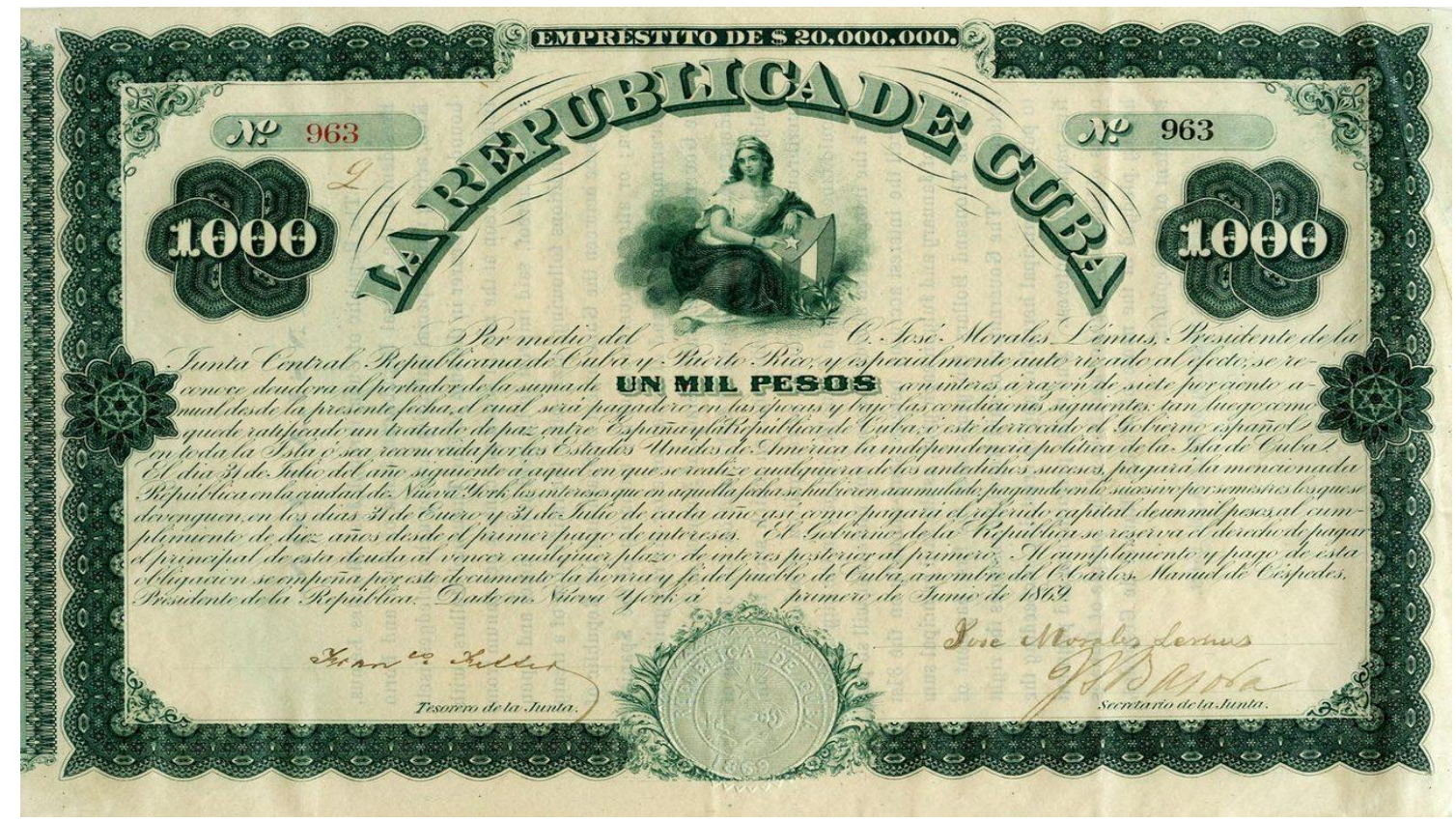

Image 1: An 1869 Cuban bond, signed by Jose Morales Lemus, the Cuban rebels' official envoy to the United States. ${ }^{60}$

\footnotetext{
${ }^{56}$ Robert E. May, Manifest Destiny’s Underworld: Filibustering in Antebellum America (Chapel Hill, 2002), 180.

${ }^{57}$ Ibid., 180-1.

${ }^{58}$ Robert E. May, The Southern Dream of a Caribbean Empire, 1854-1861 (Athens, 1989), 47-8, 63-4; and May, Manifest Destiny's Underworld, 181.

59 'The Cuban Bonds', New-York Tribune, 5 Nov 1869, 1.

${ }^{60}$ Image at http://www.havanacollectibles.com/products/1869-cuba-patriot-jose-morales-lemus-1000-pesossigned-bond.html. Accessed 25 Sep. 2015.
} 
Though printed in Spanish on its face, the reverse showed an English translation, suggesting an expected market in the Anglophone world. ${ }^{61}$ There were even rumours in the summer of 1867 of bonds being issued 'in the name of the Israelitish Government, bearing seven per cent. interest,' though the editor of the New York Jewish Messenger was quick to disavow such a scheme. ${ }^{62}$ ('The Hebrew people,' he argued, 'are not as readily imposed upon as the victims of Fenian bonds.' $)^{63}$

The Confederate States of America; republican Mexico; Walker's Nicaragua; a Cuba freed from Spanish imperial governance; and the Irish Republic: each invited Americans to speculate about the collapse of empires and the prospects of revolutionary state-building. Historians who have written of the social and cultural meaning of money have drawn attention to the fact that the stuff of financial transactions itself has a history. Money is more than (and sometimes not even an) abstract measure of value. As such, historians have rightly argued that the images displayed on financial instruments can tell us much about the political and economic imaginary of those issuing, circulating and handling those notes and coins, though generally this analysis has come in the context of existing, territorially-bounded nation-states. ${ }^{64}$ We can use bonds to gauge Irish republicans' sense of their national identity just as we can use those of Confederate or Cuban nationalists. Both the O'Mahony and Roberts bonds bore the earnest trappings of sentimental Irish nationalism - the wolfhound,

\footnotetext{
${ }^{61} \mathrm{ibid}$. According to some reports, that market was specifically members of Congress, as stories circulated of Cuban bonds being used as bribes to secure U.S. recognition of the Cuban rebels during their uprising against Spanish rule beginning in 1868. On bonds as bribery see, e.g., 'The Week - The Cuban Junta', The Nation, 9 Dec, 1869, 498-499; and the investigation into allegations of bribery detailed in Congressional Serial Set, $41^{\text {st }}$ Congress, $2^{\text {nd }}$ Session, House Report No. 104, 22 Jun. 1870.

62 'Exposure of a Fraud', New York Times, 19 Jun. 1867, 5.

63 ibid.

${ }^{64}$ John Majewski, Modernizing a Slave Economy: the Economic Vision of the Confederate Nation (Chapel Hill, 2009), esp. 140-162. See also, for instance, Helleiner, National Money; Anat First and Na'ama Sheffi, 'Borders and Banknotes: the National Perspective', Nations and Nationalism, xxi (2015), 330-347; T. Unwin and V. Hewitt, 'Banknotes and National Identity in Central and Eastern Europe', Political Geography, xx (2001). Jan Penrose is one of the few scholars who investigates the production of such notes by 'stateless nations', where the state is 'an idea' that produces 'state effects'. Her work focuses on banknote production in modern Scotland. Penrose, 'Designing the Nation: Banknotes, Banal Nationalism and Alternative Conceptions of the State', Political Geography, xxx (2011), 429-440, esp. 433-434.
} 
the round tower, the harp - complemented by the iconography of American liberty: on an O'Mahony ten, lady liberty pointing east across the sea to a rising sun; on a Roberts twenty, an eagle breaking its chain to alight on a rock marked 'Irish Independence' [Images 2 and 3]. ${ }^{65}$ The Continental Bank Note Company's 'fine specimens of engraving' featured a mechanically-produced anti-counterfeit pattern surrounding these images of nationalist icons and mythic patriotic scenes. ${ }^{66}$

The script on O'Mahony's bonds was flanked on one side by a portrait of Edward Fitzgerald, a key figure in the Irish rebellion of 1798, and on the other by one of Wolfe Tone. Tone had been a founder of the Society of United Irishmen, an anti-sectarian association dedicated to the reduction of the power of the Protestant Ascendancy in Ireland ${ }^{67}$ We might presume that his non-sectarian politics, his espousal of late eighteenth century republican thought and, perhaps, his brief American residence in exile in the mid-1790s made him an attractive figure to the Fenian Brotherhood. ${ }^{68}$ Tone may also have appealed because of his success in persuading an enemy of Britain - Revolutionary France - to take Ireland seriously in its geopolitical calculations. A less sympathetic reading might suggest that it was Tone's self-awareness - he knew full well that his final attempt at supporting insurrection in Ireland would fail - that made him an appropriate mascot for the Brotherhood.

\footnotetext{
65 \$20 here: https://oldcurrencyexchange.files.wordpress.com/2014/06/republic-of-ireland-national-bondtwenty-dollars-1867-no-373-1373-o_sullivan-scanlan-signatures-fe-8-pick-s103.jpg Accessed 25 Sep. 2015. ${ }^{66}$ No title, Evening Star (Washington D.C.), 30 Oct 1865, 4; D’Arcy, The Fenian Movement, 103. The Continental Bank Note Company was a relatively new business. It had produced bonds for the Union Treasury during the Civil War and within a few years would secure the contract to produce U.S. postage stamps. Franklin Noll, 'The United States Monopolization of Bank Note Production: Politics, Government, and the Greenback', American Nineteenth Century History, xiii (2012), 20-21. In combining a mechanical border and reproductions of detailed, artisanally-produced images, Fenian bonds sidestepped an ongoing debate about the best means of producing non-counterfeitable banknotes. See Joe Conway, 'Making Money Beautiful: Currency Connoisseurship in the Nineteenth-Century United States', Nineteenth Century Contexts: an Interdisciplinary Journal, xxxiv (2012).

${ }^{67}$ Marianne Elliott, Wolfe Tone: Prophet of Irish Independence (New Haven, 1989).

68 Tone's vision of Irish revolutionary politics appealed even to the pious conservatives at the North American Review North American Review, xxiv (1827).
} 


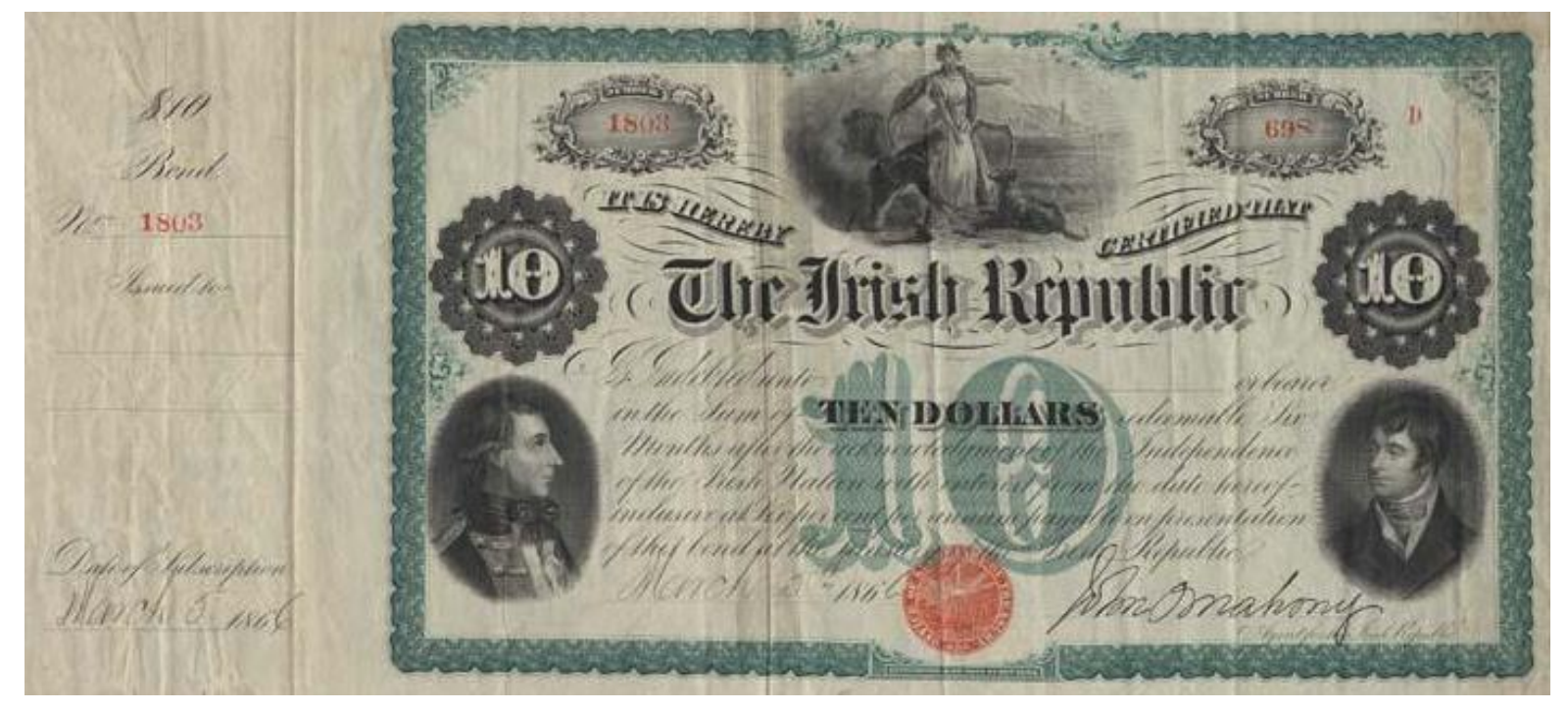

Image 2: A \$10 bond issued by John O’Mahony’s faction in March $1866 .{ }^{69}$

In addition to his prominent place on Fenian bonds his name was also used by various Fenian groups. The O'Mahony faction's ledger book details four different Wolfe Tone Circles, including one body styling itself the 'Wolfe Tone Cadets. ${ }^{70} \mathrm{He}$ was the second most popular eponym, after the celebrated nationalist martyr Robert Emmet, executed in 1803, with whom he was paired in appeals for the legitimacy of the Fenian Brotherhood as enunciating 'the true principles of Irish independence.' ${ }^{71}$ Here, on the face of the Brotherhood's bonds, this appeal to a revolutionary lineage flanked an image of Columbia hastening a Union soldier to look eastwards across the ocean: an Irish nationalist inheritance underwritten by martial experience and U.S. advocacy.

Likewise, the $\$ 20$ bonds issued by William Roberts' faction noted the Fenian Brotherhood's reliance on American power and nodded to the same revolutionary

\footnotetext{
69 Ten dollar bond signed by John O'Mahony, 5 Mar 1866, FB papers, box 3, folder 5.

${ }^{70}$ Ledger of Accounts, 1865-1867, FB papers, box 3, folder 1, 285.

71 'Address of the Second Congress of the Fenian Brotherhood... to the Irish of America', in Second National Congress, 46.
} 
inheritance. Again, the portraits of two stalwart heroes embellished the promise of financial pay-off. One was John Barry, who was born in County Wexford, emigrated to Pennsylvania in 1760, and later regarded as 'the patriarch of the American Navy. ${ }^{, 72}$ The second, Richard Montgomery, offered a more literal and ominous hint at the Roberts faction's intentions. Dublin-born Montgomery had emigrated to New York in the 1770s and, as Brigadier General, seized Montreal for the Continental Congress before dying in a failed attempt to take Quebec in late $1775 .{ }^{73}$ The blend of historical iconography and windswept scenery on each bond was the Continental Bank Note Company’s stock-in-trade, as evidenced by an 1873 yen note that the Company produced for the Japanese government [Image 4]. More generally, this portraiture of national heroes and the emphasis on revolutionary lineage reflected a mid-century commitment to using banknotes as a vehicle for naturalising national identification, historicising present nationalist claims, and educating citizenry. ${ }^{74}$ This could happen in a bounded territorial space, as historian Eric Helleiner has highlighted, but the Fenian case suggests that this could be as much about engendering national attachment outside that territorial space - in a diasporic context - as it was about legitimating state capacity within it. $^{75}$

\footnotetext{
72 On Barry, see Robert G. Baker, 'Barry, John', in the American National Biography Online at http://www.anb.org/articles/02/02-00021.html. Accessed 30 Sept 2015.

${ }^{73}$ Mark R. Anderson, The Battle for the Fourteenth Colony: America's War of Liberation in Canada, 1774 1776 (Hanover, NH, 2013), esp. 182-199. On \$10 Scanlan bonds Montgomery's place was taken by Thomas Davis, a journalist and writer at the forefront of the Young Ireland movement, which emphasised the cultivation of national culture. On this see R. F. Foster, Modern Ireland 1600-1972 (London, 1989), 310-317.

${ }^{74}$ Marcia Pointon, 'Money and Nationalism' in Geoffrey Cubitt (ed.) Imagining Nations (Manchester, 1998).

${ }^{75}$ Helleiner, National Money, 100-120.
} 


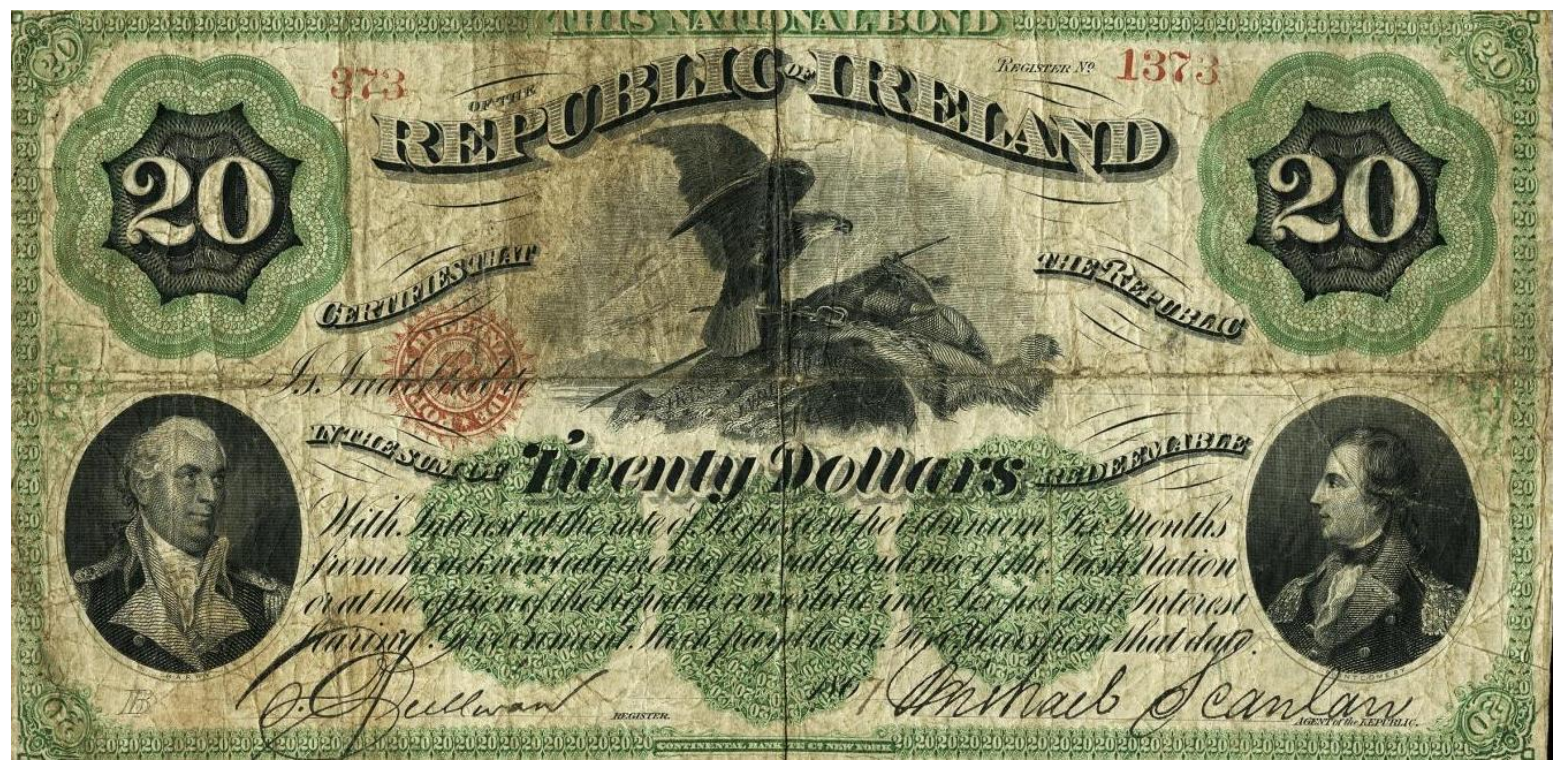

Image 3: A \$20 bond issued by William Roberts's faction in $1867 .{ }^{76}$

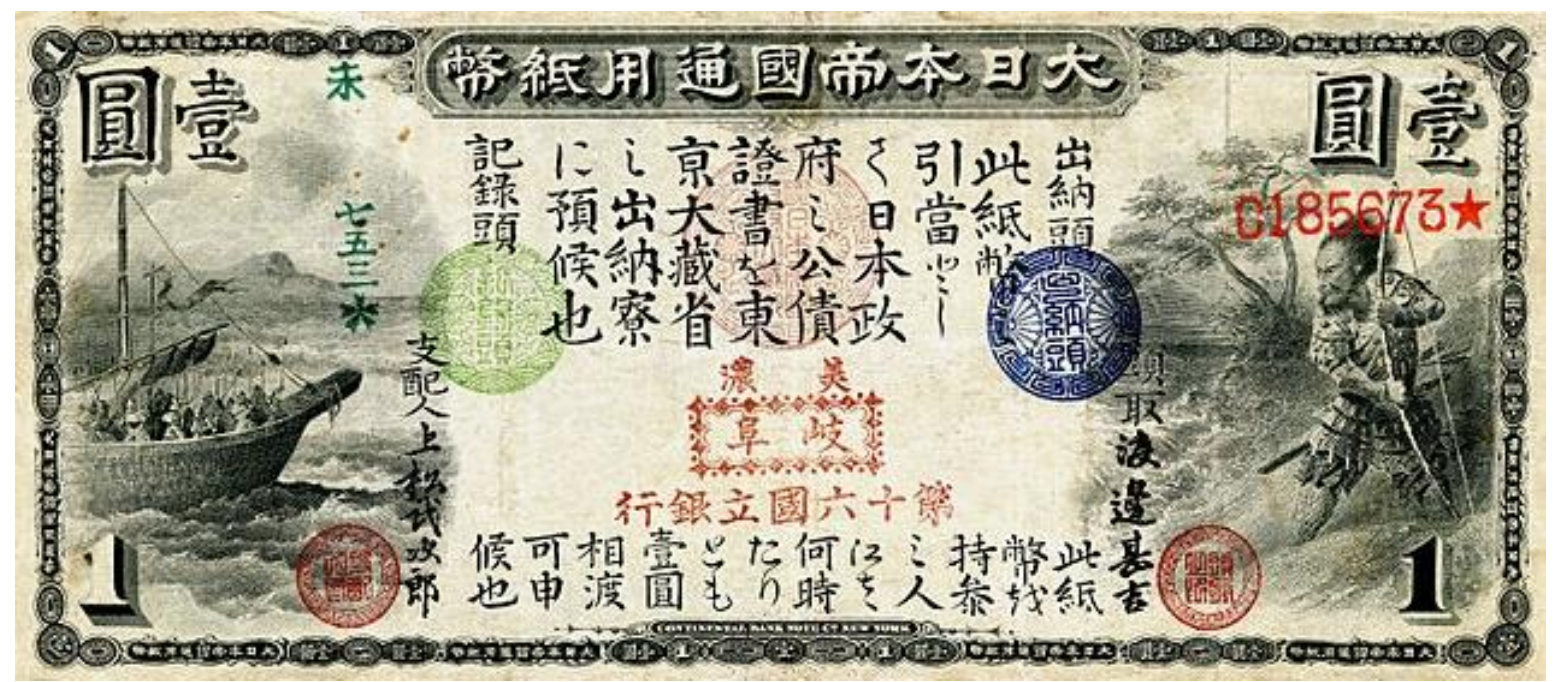

Image 4: a ¥1 bank note produced by the Continental Bank Note Company in the early 1870 s. $^{77}$

\footnotetext{
76 Twenty dollar bond signed by Michael Scanlan, 1867, accessed via the Old Currency Exchange website at: http://oldcurrencyexchange.com/central-bank-of-ireland-banknotes/ Accessed 4 Mar. 2016.

${ }_{77}$ One yen bank note dating from 1873, accessed via the Origins: Current Events in Historical Perspective website, hosted by Ohio State University and Miami University in Oxford, Ohio at:

https://origins.osu.edu/article/4332/images. Accessed 4 Mar. 2016. Helleiner, National Money, 103-104.
} 
Each bond, of course, also carried a promise and, by implication, the projection of a future Irish nation. The ten dollar bond that John Maloney, a member of Williamsburg's Hamilton Rowan Circle, carried home to his house at 103 Grand Street was typical. ${ }^{78}$ It promised that the Irish Republic was in Maloney's debt 'in the sum of TEN DOLLARS redeemable Six Months after the acknowledgment of the Independence of the Irish Nation with interest from the date hereof inclusive at Six per cent per annum payable on presentation of this bond at the Treasury of the Irish Republic. ${ }^{79}$ With this commitment came a disavowal: allegiance to the hypothetical republic entailed rejection of British subjecthood. ${ }^{80}$ Many prominent scholars have followed Marx and offered cultural and social theories of value and monetary exchange situated within histories of modernity and, more specifically, of capitalism. ${ }^{81}$ We should think of Fenian bonds within two additional frames of reference. The first, most obviously, is nationalism. ${ }^{82}$ Ideologically, the bond that Maloney carried home helped collapse the distance between Williamsburg and an identified homeland. Materially, the bond allowed Maloney to do more than simply gift money to a distant recipient. Both he and the hypothetical nation were in some way enacting sovereignty through this transaction, and he personally shouldered some small responsibility for the creation of the republic.

Second, Fenian bonds were necessarily anti-imperial. Handling them was an anti-imperial

\footnotetext{
78 'Hamilton Rowan Circle', Ledger of Accounts, 1865-1867, FB papers, box 3, folder 1, 239.

${ }^{79}$ Ten dollar bond, FB papers, box 3, folder 5. 6\% p.a. was a reasonable if unexceptional return for a contemporary bond. As noted, Mexican bonds issued in the mid-1860s carried the same rate of interest, as did, for instance, those promised by the United States in July 1862 to help fund the Union Pacific Railroad.

${ }^{80}$ On the conflict between American citizenship, Irish nationalism, and British subjecthood, see David Sim, A Union Forever: the Irish Question and U.S. Foreign Relations (Ithaca, NY, 2013), 97-128.

${ }^{81}$ Walter Benjamin, Reflections: Essays, Aphorisms, Autobiographical Writings (trans. By Edmund Jephcott, edited by Peter Demetz), 87; Georg Simmel, The Philosophy of Money (trans. Tom Bottomore and David Frisby, edited by David Frisby), $2^{\text {nd }}$ edn, (London, 1990), 59-280. On connections between the two, see Frisby's 'Preface to the Second Edition', esp. xxvi. See also William M. Reddy, Money and Liberty in Modern Europe: A Critique of Historical Understanding (Cambridge, 1987), 62-106. And for an excellent overview of theorists of "market" and "special" money, see Zelizer, 'Social Meaning of Money', 344-353.

${ }^{82}$ See Timothy R. Dougherty, 'Lost in TransNation: the Limits of Constitutive Nationalism in the Fenian Movement', Rhetoric Society Quarterly, xlv (2015), 348-9, 357; Helleiner, National Money, esp. 100-120; and, of course, Benedict Anderson, Imagined Communities: Reflections on the Origin and Spread of Nationalism (London, 2006, rev. edn).
} 
act, and their imagery reached beyond the nation-less status that the British state accorded Ireland. ${ }^{83}$ These financial instruments were not adorned with doughy founding fathers or the originators of a national bank, but those whom the Brotherhood believed had defied British law and custom to build a tradition of Irish separatism.

III

The Fenian Brotherhood issued bonds for a relatively short period, and even during this time the money raised by their sale proved insufficient for the organisation's activities. At a major Fenian meeting in Jones's Wood on New York's upper east side in March 1866, sales of bonds 'were quite languid' despite the best efforts of various Fenian orators. ${ }^{84}$ According an internal circular of April 1870, the Canadian invasions of 1866 for which the Brotherhood is now best known were underwritten not by the proceeds of bond sales but by the personal contributions of Fenian Senators. By 1868 the Brotherhood's financial needs led its then president, John O’Neill, to recommend shaking down hibernophilic politicians at election time. ${ }^{85}$ However, the public spectacle of agents selling bonds convinced contemporaries of their importance. A high-ranking British informant recalled that no means of raising money 'was more successful than the issue of Fenian bonds.' The 'simple souls' who subscribed 'were quite ready to part with their little all, in the belief that later on... they would be repaid with interest,' he continued, and 'very many of the persons displaying this credulity were

\footnotetext{
${ }^{83}$ In this there is a parallel with the banknotes of post-Soviet states, that sidestepped the immediate past in favour of an older, heroic period. See Unwin and Hewitt, 'Banknotes', 1025.

${ }^{84}$ The New York Times, hardly a sympathetic observer, reported a crowd of 100,000. 'Great Fenian Demonstration', 5 Mar. 1866, 8.

${ }^{85}$ James Gibbons to the Officers and Members of the F.B., 7 Apr. 1870, and John O'Neill to "Sir \& Bro.", 6 Oct 1868, both accessed via VUDL at http://digital.library.villanova.edu/Item/vudl:249716 and http://digital.library.villanova.edu/Item/vudl:249963 respectively. Accessed 4 Sep. 2015.
} 
Irish girls in service... and thus came into vogue the sneering reference to the agitation being financed by the servant-girls of New York. ${ }^{86}$

Discussion of investment in Fenian bonds was framed in gendered terms and commentators often focused on the threat to the domestic finances of working class Irishmen and, especially, working class women, as the marketers of bonds were presumed to prey on their wide-eyed patriotism. 'The Fenian scheme is... desperate,' wrote one newspaper 'for thousands of impulsive and thoughtless Irishmen and women may invest in it money [of] which they and their families are in need. ${ }^{87}$ Worse, 'credulous Irishmen and hard-working servant girls' might be duped by one of the fraudulent bonds that the New York Times reported as being in circulation in the city in spring 1866, despite the best efforts of the Continental Bank Note Company. ${ }^{88}$ 'Three presses have been running... on a very accurate counterfeit of the Fenian bonds of various denominations,' the paper stated, suggesting the work of British agents. ${ }^{89}$ As historian Niall Whelehan has argued, the Fenians were often lampooned through images of 'the Irish domestic servant handing over her savings to perfidious patriots. ${ }^{90}$ These formulations, which delegitimised Fenian activity, questioned the honesty of nationalist organisers, and offered a paternalist characterisation of working class Irish women, found their way into British consular reports and the writings of British spies.

Historians have not always agreed about the role of working class Irish American women in transatlantic nationalist movements but there is a consensus that such women

\footnotetext{
${ }^{86}$ Henri Le Caron, Twenty-Five Years in the Secret Service: The Recollections of a Spy (London, 1892), 27-28; Christy Campbell, Fenian Fire: the British Government Plot to Assassinate Queen Victoria (London, 2002), 82, 374; Brian Jenkins, The Fenian Problem: Insurgency and Terrorism in a Liberal State 1858-1874 (Liverpool, 2009), 171.

87 'Beware of the Mexicans and the Fenians', Wheeling Daily Intelligencer, 1 Nov. 1865, p2.

88 'Counterfeiting the bonds of the Irish Republic', 11 Mar. 1866, 5.

89 Ibid.

${ }^{90}$ Niall Whelehan, The Dynamiters: Irish Nationalism and Political Violence in the Wider World, 1867-1900

(Cambridge, 2012), 234-245, quotation at 234.
} 
experienced greater occupational mobility than Irish American men, and that their disposable income underpinned a wide range of Irish American organisations. ${ }^{91}$ A Fenian Sisterhood operated alongside the Brotherhood, and again worked publicly to promote the sale of bonds as well as providing support for Fenian prisoners and encouraging a sense of national 'regeneration. ${ }^{92}$ For Ellen Mahoney [also rendered Ellen O’Mahony], the Head Directress of the Fenian Sisterhood, bond purchases were an attractive alternative to the process of remitting money home, which she saw as propping up British authority in Ireland. ${ }^{93}$ The O’Mahony ledger book details two Sisterhood circles - there were at least fourteen more and one female bond agent, Alice McNamara, who sold $\$ 300$ of bonds between them. ${ }^{94}$ This represented sale of just over $60 \%$ of the bonds taken, well above the average rate of sale.

Cross referencing the names - mostly the names of bond agents - gleaned from the Fenian ledger and from the later correspondence of Fenian bondholders with available census records and city directories generates a profile of those who engaged in this everyday diasporic nationalism through the purchase of the Brotherhood's bonds.. John Maloney was a tailor living in Williamsburg, Brooklyn. ${ }^{95}$ Denis Hyland, a grocer and relatively successful bond agent, lived in Brooklyn, too, as did saddler Andrew Christian, who purchased a $\$ 10$

\footnotetext{
Hasia Diner, Erin's Daughters in America: Irish Immigrant Women in the Nineteenth Century (Baltimore, ${ }^{91}$ 1983), 71, 90-2; Diane M. Hotton-Summers, 'Relinquishing and Reclaiming Independence: Irish Domestic Servants, American Middle-Class Mistresses, and Assimilation, 1850-1890', in Kevin Kenny (ed.) New Directions in Irish-American History (Madison, 2003), 227-242. Ely M. Janis takes Hasia Diner and others to task for overlooking female contributions to nationalist activity in his A Greater Ireland: the Land League and Transatlantic Nationalism in Gilded Age America (Madison, 2015), 137-138, and 237-238, fn.1. On the earnings and savings of Civil War era Irish immigrants, see Tyler Anbinder, "Moving Beyond "Rags to Riches": New York's Irish Famine Immigrants and Their Surprising Savings Accounts', Journal of American History, xcix (2012).

92 Mary C. Kelly, The Shamrock and the Lily: the New York Irish and the Creation of a Transatlantic Identity, 1845-1921 (New York, 2005), 57-59, quotation at 57; Rose Irene Novak, 'Writing Ireland's Wrongs:

Nineteenth-Century Women, Politics, and Violence' (unpubld PhD dissertation, University of Connecticut, 2010); Steward and McGovern, 65-66, 102.

${ }^{93}$ Kelly, Shamrock, 58; 'News Items', The Spirit of Democracy (Woodsfield, Oh.), 27 Dec. 1865, 2; on remittances more generally, see Doan, 'Green Gold', 273-378. I have not been able to ascertain whether Ellen O’Mahony and John O’Mahony were related.

94 'Lavelle Sisterhood', 'James Stephens Sisterhood', 'Alice McNamara', Ledger of Accounts, 1865-1867, FB papers, box 3, folder 1, 189, 196, 286; Steward and McGovern, The Fenians, 78.

${ }^{95}$ The Brooklyn City Directory... 1866 (Brooklyn, 1865), 320.
} 
bond in April 1866. ${ }^{96}$ According to the 1880 federal census, Mary McLester kept house at her home on Clarkson Street in Greenwich Village; her husband was listed as a 'packer.'97

Thomas H. Greelis was a 28-year old labourer living in Watervliet, just north of Albany, when he purchased a $\$ 20$ Fenian bond. ${ }^{98}$ John McCullough of New Bedford, Massachusetts, moved $\$ 360$ of the $\$ 1000$ worth of bonds he took for sale; in the 1870 federal census he was recorded as a 49-year old father of nine, Irish-born, and a relatively affluent junk dealer. ${ }^{99}$ William Murray, a Boston agent who sold over $\$ 5000$ worth of bonds, owned a clothing warehouse in the city’s North End. ${ }^{100}$ John Madigan ran a saloon in Columbus, Ohio, and raised $\$ 500$ for the Brotherhood. ${ }^{101}$ Of those names identifiable in census records, all were Irish-born and, at the time of the census used here, in employment, married, and with children.

\footnotetext{
96 'Denis Hyland's Bond Account', and 'Pierce Sheehan, Brooklyn', Ledger of Accounts, 1865-1867, FB papers, box 3, folder 1, 44, 70; P. S. Ó Muireadhaigh to Thomas A. Healy, 26 May 1938, TSCH/3/5749A, National Archives of Ireland [hereafter NAI]; 'Andrew Christian', ward 20, Brooklyn, Kings, New York, United States; citing source p. 42, line 35, household ID 292, State Library, Albany [hereafter SL/Alb]; FHL microfilm 1,930,211, in 'New York State Census, 1865' database with images [hereafter NY Census 1865], accessed via FamilySearch at https://familysearch.org/ark:/61903/1:1:QVNV-Q9YY Accessed 28 Jan. 2016; Brooklyn City Directory... 1866, 86, 256. Hyland sold $\$ 340$ of the $\$ 390$ worth of bonds that he took for sale.

97 'Mary McLester', New York, New York, United States; citing enumeration district ED 218, sheet 297B, NARA microfilm publication T9 (Washington D.C.: National Archives and Records Administration, n.d.) roll 0877; FHL microfilm 1,254,877, in 'United States Census, 1880' database with images, accessed via FamilySearch at https://familysearch.org.ark:/61903/1:1:MZ6W-3DC Accessed 3 Feb. 2016. Mary McLester tracked via her daughter, Elizabeth, in the 1940 census. Elizabeth McLester to Éamon de Valera, 2 Aug. 1951, TSCH/3/S5749A, NAI.

98 J. H. Greelis to Pres. de Valera, 17 Mar 1945, TSCH/3/S5749A, NAI. The Greelis family tracked via the 1940 and 1880 federal censuses. Thomas H. Greelis listed as 'Thomas Greelis', district 01, Watervliet, Albany, New York, United States; citing source p. 66, line 1, household ID 452, SL/Alb; FHL microfilm 521,929, in NY Census 1865, accessed via FamilySearch at https://familysearch.org/ark:/61903/1:1:QVNF-16GY Accessed 28 Jan. 2016.

99 'John Mc Cullough, New Bedford', Ledger of Accounts, 1865-1867, FB papers, box 3, folder 1, 64; 'John Mccullough', Massachusetts, United States; citing p. 13, family 114, NARA microfilm publication M593 (Washington D.C.: National Archives and Records Administration, n.d.); FHL microfilm 552,104, in 'United States Census, 1870’ database with images [hereafter U.S. Census 1870], accessed via FamilySearch at https://familysearch.org/ark:/61903/1:1:MDSL-7XX Accessed 3 Feb. 2016.

100 'William Murray Agt.', in Ledger of Accounts 1865-1867, FB papers, box 3, folder 1, 50; The Boston Directory... for the year commencing July 1, 1865 (Boston, 1865) accessed via Tufts University's 'Boston Streets: Mapping Directory Data' project at http://dca.lib.tufts.edu/features/bostonstreets/people/directories.html Accessed 3 Feb. 2016.

101 'John Maddigan', in Ledger of Accounts 1865-1867, FB papers, box 3, folder 1, 138; in census listed as 'John Madigan', Ohio, United States, citing p. 66, family 518, U.S. Census 1870, accessed via FamilySearch at https://familysearch.org/ark:/61903/1:1:M623-NQP Accessed 3 Feb. 2016.
} 
The bonds of the Irish Republic were not unknown outside the borders of the United States, although, as one might expect, they circulated much less widely. Bond agents were active in Montreal and Toronto, and contemporaries reported tales of Fenian soldiers on the Canadian border offering bonds to residents as compensation for food and horses that they had taken. ${ }^{102}$ The O'Mahony faction, at least, used bonds as a form of performance-related pay, as the salary structure of Fenian Brotherhood officers included 'deferred compensation' in the form of bonds. ${ }^{103}$ In addition, the Brotherhood forwarded $\$ 20,000$ worth of bonds to Paris for John Mitchel to distribute but, as he noted, floating a foreign loan required authorisation from the French government, which was not forthcoming. ${ }^{104}$ James Stephens, as head of the Irish Republican Brotherhood, took $\$ 10,000$ worth of these bonds back from Mitchel, presumably with the intention of selling them in Ireland, though we have no evidence that this somewhat unlikely project developed any further. ${ }^{105}$ A comedic, unofficial effort to sell bonds in the very heart of the empire was rumbled by Scotland Yard, who gave the offending American Fenian three days to leave London. He did. ${ }^{106}$ Yet, through the 1940s and 1950s, the Irish government received letters asking for information about the redemption of Fenian bonds from Jamaica, Wales, England, Australia, and Canada, suggesting a diasporic circulation for these bonds, beyond the borders of the United States. ${ }^{107}$

\footnotetext{
${ }^{102}$ Brian P. Clarke, Piety and Nationalism: Lay Voluntary Associations and the Creation of an Irish-Catholic Community in Toronto, 1850-1895 (Montreal, 1993), 169-170; account of George Warren, of the Buffalo Western Union Telegraph Office, in The Fenian Raid at Fort Erie (Toronto, 1866), 32; 'Miscellaneous', New York Herald, 23 Oct. 1865, 4.

${ }^{103}$ Steward and McGovern, Fenians, 79.

104 'John Mitchell [sic], Paris,' in Ledger of Accounts, 1865-1867, FB papers, box 3, folder 1, 100; Mitchel to O'Mahony, 10 Mar 1866, FB papers, box 1, folder 9; Viner, 'Political Aspects of International Finance', 158160.

${ }^{105}$ John Mitchel to John O'Mahony, 7 Apr 1866, FB papers, box 1, folder 9.

${ }^{106}$ Patrick R. Redmond, The Irish and the Making of American Sport, 1835-1920 (Jefferson, NC, 2014), 105.

${ }^{107}$ Fr. Leo T. Butler [Jamaica] to Éamon de Valera, 3 Jan. 1946, TSCH/3/S5749A, NAI; Rev. P. J. Gibbons [Aberkenfig, South Wales] to Frank Aiken, 10 Aug. 1953; anon. [London, England] on behalf of Mrs. O'Heeney, to the Department of Foreign Affairs, 11 May 1953; John J. Byrne [Queensland, Australian] to the Department of External Affairs, 31 Jul. 1949; Winifred Branagan [Victoria, Australia] to Dr. T. J. Kiernan, 25 Oct. 1946; John J. Hearne [Ottawa, Canada] to the Department of External Affairs, 24 Apr. 1940, all DFA/6/405/28, NAI.
} 
Whilst the Irish Republican Brotherhood laboured in secrecy, the U.S.-based Fenian Brotherhood was free to act publicly and with impunity. The organisation put a premium on spectacle through military parades, fairs, and picnics, which provided a social space for members and an opportunity to raise funds. ${ }^{108}$ And publishing the records of Fenian meetings would create a virtuous circle, claimed one Philadelphian bond agent, as would trumpeting news of investments in the Fenian cause. ${ }^{109}$ Was so brazen a bond issue legal? Almost certainly. According to a contemporary newspaper report, the Continental Bank Note Company had required and received legal assurances that it was acting within the law in producing bonds for the Brotherhood. ${ }^{110}$ The act governing U.S. neutrality dated from 1818 and was intended to prevent American citizens aiding Latin American revolutionaries without the support of their government, and was both limited and nearly impossible to enforce where local officials had any sympathy with the cause at issue. ${ }^{111}$ (There is no evidence, for instance, that the U.S. government ever tried to restrain individuals who issued Cuban or Nicaraguan bonds.)

This highlights the limited capacity of the American state to interfere with its citizens enthusiasm for distant revolutions. In the mid-1850s British statesmen had pressed the federal government to offer stronger opposition to Irish republican organisations in the United States. In a candid but firm statement of the U.S. government's position, Attorney General Caleb Cushing wrote that an effort to change another country's political institutions was

\footnotetext{
108 Steward and McGovern, The Fenians, 81.

109 John Hasson to P. H. Connor, 1 Mar. 1866, Fenian papers, box 1, folder 9. Hasson sold $\$ 850$ of the $\$ 1000$ worth of bonds that he took for sale. 'John Hasson', Ledger of Accounts, 1865-1867, FB papers, box 3, folder 1. 110 'The Irish Bonds', New York Herald, 26 Oct. 1865, 4.

${ }^{111}$ George Bemis, a contemporary scholar of international law, was deeply critical of the U.S. neutrality law and contrasted it unfavourably with its British counterpart. His American Neutrality: Its Honorable Past, Its Expedient Future (Boston, 1866) was cited by British negotiators during the Geneva arbitration in 1872. Foreign Relations of the United States [hereafter FRUS]: 1872, part II (vol. II): Geneva Arbitration (Washington D.C., 1872), 404-405. See also James E. Lewis, Jr., The American Union and the Problem of Neighborhood: the United States and the Collapse of the Spanish Empire, 1783-1829 (Chapel Hill, 1998), 109; Amy Greenberg, Manifest Manhood and Antebellum American Empire (Cambridge, 2005), 29-30; and ${ }^{111}$ Sim, A Union Forever, 69-96.
} 
'undoubtedly a violation of national amity and comity' but that there was 'no law in the United States to forbid this. ${ }^{112}$ Government restraint would follow only when 'the spirit of interference... reaches its natural consummation, that of attempts to interfere in the affairs of foreign countries by force. ${ }^{\text {'13 }}$ This was the government's response to the Fenian movement of the 1860s: federal intervention followed only once the Brotherhood had launched its raids into Canada. All this left the mechanics of organising for revolution, including its financing, beyond the remit of law enforcement.

The obviously public nature of Fenian bonds may not have troubled U.S. authorities, but it posed difficulties for the Fenian Brotherhood in a different context. Open, performative, and accessible diasporic nationalism was also open and accessible to British and Irish prosecutors. According to nationalist agitator John Devoy, a Fenian bond bearing O’Mahony's signature, was seized by British police and used by government lawyers in late 1865 as part of the case to prove the existence of an international conspiracy. ${ }^{114}$ The ease with which the British government could fashion the criminal charges out of the slightest connection with Fenian activity in either Ireland or the United States made the subversive act of owning a bond a treasonable one, too. As one Irish-American, arrested for his part in a Fenian filibustering expedition, argued, nothing stopped informants swearing that they 'saw him at a public [Fenian Brotherhood] meeting in America, saw an Irish bond hanging up behind his counter, or a saw a name to correspond with his published... as having spoke [sic] or written in favor of republicanism. ${ }^{, 15}$

\footnotetext{
112 Cushing quoted in Sim, Union Forever, 80

113 Ibid.

John Devoy, Recollections of an Irish Rebel (New York, 1929), 302. ${ }^{114}$

115 John Warren quoted in Sim, Union Forever, 113. Warren managed to keep a straight face. He had, in fact, worked as a bond agent in Salem, Massachusetts in 1866. 'John Warren: Salem, Mass', Ledger of Accounts, 1865-1867, FB papers, box 3, folder 1, 98.
} 
As the prospect of a successful Irish revolution faded, the term 'Fenian bond' became a synonym for a quixotic venture and a worthless investment. After the arrest of Fenian soldiers in Ontario in June 1866, the Toronto Daily Telegraph sarcastically asked whether the prisoners could pay their bail with Fenian bonds. ${ }^{116}$ Volatile Spanish bonds; money risked against a disreputable filibustering expedition in Turkey; and outstanding First World War debts that would never be repaid were all compared to or described as 'Fenian bonds'. ${ }^{117}$ The 'true Fenian Bonds,' suggested Punch wryly, was 'a good pair of handcuffs.' ${ }^{\text {'18 }}$ And the analogy of Fenian bonds was used to disabuse those European investors who hoped that the reconstructed United States would honour Confederate war debts. ${ }^{119}$

This pairing of Confederate and Fenian bonds was a valued rhetorical device but it also usefully reflected a sense of moral equivalence: U.S. toleration of the Fenian Brotherhood's activities mirrored Britain's apparent encouragement of the Confederate rebellion. Fenian bonds, suggested one Illinois newspaper, 'will doubtless become as popular in Wall street as did the Confederate bonds at the Royal Exchange or the Paris Bourse.' ${ }^{120}$ And just as the British government was fully aware that the Fenian Brotherhood purchased arms and ammunition in the United States - mostly from former Union arsenals - so Americans were well informed about the Confederacy's acquisition of war materiel in Britain. ${ }^{121}$ This sense of parity had, in turn, consequences for Anglo-American relations in the post-Civil War era. At the same time as the value of Fenian bonds collapsed, their diplomatic capital increased. The British government, keen to find some counterweight to American

\footnotetext{
${ }^{116}$ W. S. Neidhardt, Fenianism in North America (University Park, Penn., 1975), 145 fn. 34.

117 'Affairs in Spain', Colburn's United States Service Magazine, and Naval and Military Journal, lv (May 1869): 73; Victountess Strangford (ed.), A Selection from the Writings of Viscount Strangford on Political, Geographic, and Social Subjects, 2 vols. (London, 1869), ii, 167; Peter L. Robertson, World Reorganization or Downfall, and the Remedy (Hamilton, Ont., 1932), 95-96.

${ }^{118}$ Punch, 15 Feb. 1868, 76.

${ }^{119}$ Rhodes Journal of Banking for the Year 1883, (New York, 1883), 10: 639; Weidenmier, 'Confederate Cotton Bonds', 93-94.

120 'The Fenian Movement', Cairo Evening Times (Cario, Ill.), 12 Oct. 1865, 1.

${ }^{121}$ Weidenmier, 'Southern Confederacy', 414.
} 
claims for reparations for British actions during the Civil War, seized on Fenian activities as demonstrating the flimsiness of U.S. neutrality. The Fenian bond comprised a part of this case and in the intergovernmental negotiations over outstanding Civil War claims in the spring of 1872 , the bonds' text and production were detailed in the British counterclaim. ${ }^{122}$ British lawyers dug over John O'Mahony's speech to the Fenian faithful in January 1865, presenting the issuance of bonds as part of a broader attempt to build a disciplined, sustained movement to contest British rule in Ireland. The British case also cited a New York World article of early March 1866, which had breathlessly reported that the 'Fenian funds are disproportioned to any pacific objects. They mean war or they mean nothing., ${ }^{123}$

Here the Fenian bond was wielded as a diplomatic tool, but it was also moulded into a broader critique of American foreign policy. The British government's delegation at Geneva, led by the dyspeptic Lord Chief Justice Alexander Cockburn, wrote a stinging assessment of the American case that highlighted the elisions, inefficacy and hypocrisy of U.S. diplomacy in its response to - and collusion with - distant revolutions. The U.S. government, according to one commentator, regarded itself as having 'steadily adhered to principles of international neutrality... at whatever hazard of domestic or foreign inconvenience,' but this was fiction. ${ }^{124}$ The British representatives argued that 'however rigorously the United States may now be disposed to estimate the obligations of other powers, they have not so construed their own.'125 Rather, the historical record showed only 'the impunity with which armed expeditions have

\footnotetext{
${ }^{122}$ Bonds detailed in FRUS: 1872, part II (vol. II): Geneva Arbitration, 254. The British claims that resulted from the Fenian raids were characterised by the British government as 'indirect' and 'of a constructive and inferential character' and were ultimately dropped on the understanding that the United States would likewise drop its indirect and inferential claims. The American representatives did not do so, leading to serious tension between the parties. Earl Granville to Edward Thornton, 13 May 1872, ibid., 511-513, quotations at 512; Adrian Cook, The Alabama Claims: American Politics and Anglo-American Relations, 1865-1872 (Ithaca, NY, 1975), 207-232.

${ }^{123}$ FRUS: 1872, part II (vol II): Geneva Arbitration, 254-255.

${ }^{124}$ Cook, Alabama Claims, 207, 238-9; Viscount Bury, Balance Sheet of the Treaty of Washington of 1872, in Account with the People of Great Britain and Her Colonies (London, 1872), 25.

${ }^{125}$ FRUS: 1872, part II (vol II): Geneva Arbitration, 262.
} 
been repeatedly, and with little or no attempt at concealment, organized within the United States. ${ }^{\text {'26 }}$ The history of the United States' attitude to neutral obligations was 'from first to last a history of unlawful enterprises,' taking in 'Great Britain, Spain, Portugal, Mexico, the Central American Republics, Cuba, and Canada.' In each case the song remained the same: 'some scheme of annexation, or other form of invasion is started, public meetings of sympathisers are held, a reckless soldier of fortune is selected for chief, funds are raised by bonds... arms are collected, recruits advertised... and at length a certain number of men are got together and embark. ${ }^{, 27}$ From this perspective, occasional disregard for the norms of international comity was woven into the fabric of American statecraft. From another, this was simply a description of the inevitably messy and inevitably contested processes employed by nationalist, secessionist, and anti-imperialist non-state actors as they sought to leverage the forms of nation-state legitimacy - including the mechanics of fund raising - in the service of national self-realisation.

IV

In the course of 1919, the provisional government of the Irish Republic floated another iteration of nationalist bonds on the American market. The war of independence that spun out of the Easter Rising and the bloody reprisals of the British government required funds; the United States, with its large Irish diaspora, was an obvious place to look. ${ }^{128}$ By contrast with those issued in the 1860s, these bonds were authorised not by an American auxiliary but by statesmen in Ireland proper. The legality of this effort was more obviously contestable as, in

\footnotetext{
126 ibid., 248.

${ }^{127}$ Bury, Balance Sheet, 25.

${ }^{128}$ The best studies of this bond drive are Francis M. Carroll, Money for Ireland: Finance, Diplomacy, Politics, and the First Dáil Éireann Loans, 1919-1936 (Westport, Conn., 2002), and Lainer-Vos, Sinews of the Nation.
} 
an effort to better oversee domestic securities, several U.S. states now regulated the marketing and sale of bonds. ${ }^{129}$ Under legal advisement (including that of Franklin D. Roosevelt, then of New York law firm Emmet, Marvin and Martin) representatives of the provisional Irish government engineered a workaround. Instead of bonds, subscribers to the nationalist cause in the United States would instead receive a 'Bond Certificate,' or the promise of a future promise. ${ }^{130}$ Roosevelt's manoeuvres did little to appease the U.S. State Department, however, which maintained 'a firm policy against' not just the transmission of funds but also their initial sale so as 'to prevent our territory [being used] to further rebellion against a friendly nation,' alongside whom the United States had just fought. ${ }^{131}$

By contrast with the Fenian bonds of the 1860s, the Bond Certificates were altogether more sober, more legalistic, and less spectacular, though they reflected the impact of Gaelic Revival on Irish political culture [Image 5].

\footnotetext{
${ }^{129}$ Carroll, Money for Ireland, 17; Macey \& Miller, 'Origin of the Blue Sky Laws' Texan Law Review, 1xx (1991); Julia Ott, "“The Free and Open People's Market”: Political Ideology and Retail Brokerage at the New York Stock Exchange, 1913-1933', Journal of American History, xcvi (2009), 48-49.

${ }^{130}$ Coogan, De Valera: Long Fellow, Long Shadow, 157-8.

${ }^{131}$ State Department official, ca. Feb. 1920, quoted in David Fitzpatrick, Harry Boland's Irish Revolution, 1887-1922 (Cork, 2003), 145.
} 


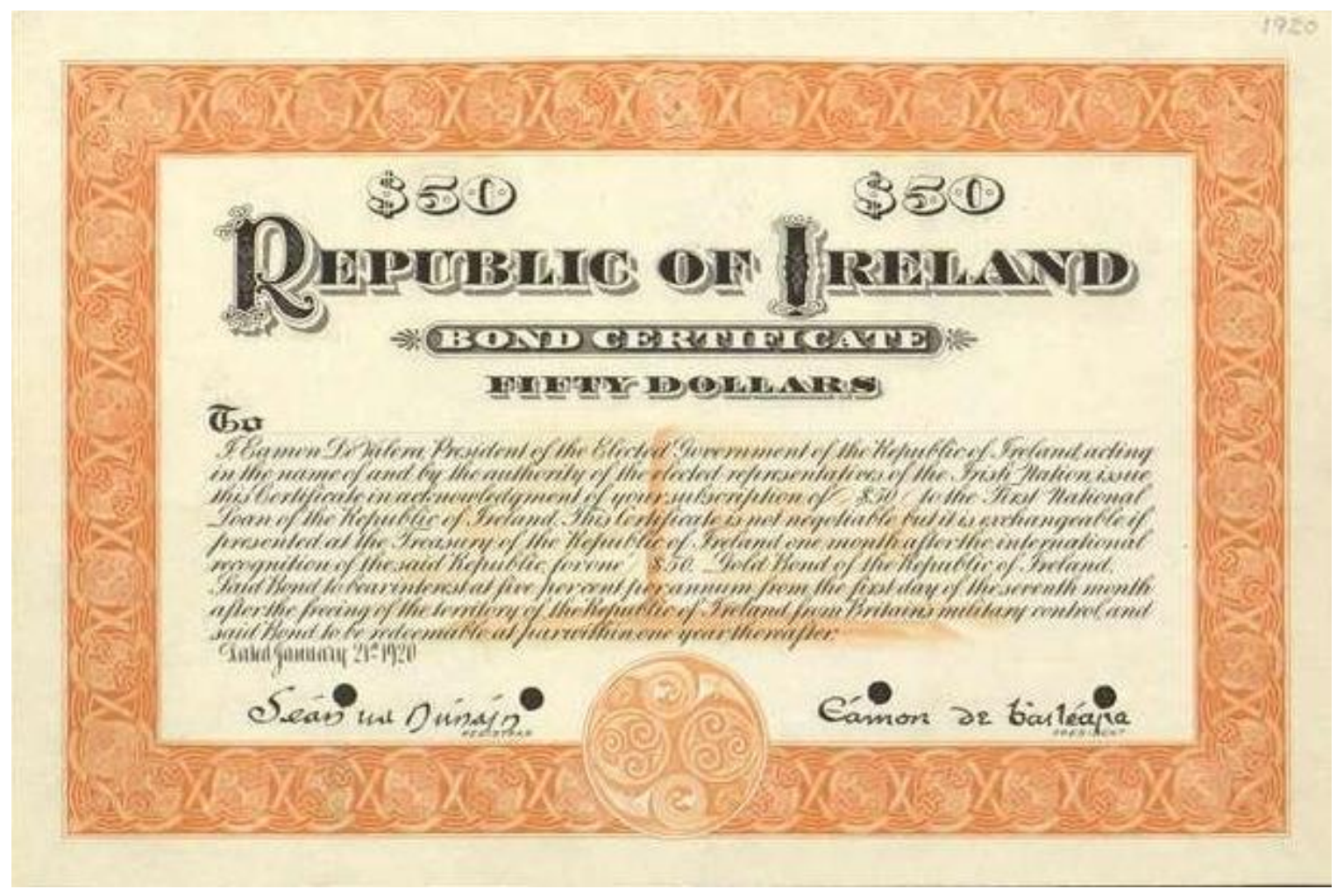

Image 5: A $\$ 50$ bond of the prospective Republic of Ireland, dated 21 January $1920 .{ }^{132}$

These certificates were more precise in detailing the obligation they entailed. 'One month after the international recognition of the [Irish] Republic,' the bearer could present their Bond Certificate at the Republic's Treasury in exchange for a 'Gold Bond of the Republic of Ireland,' which would in turn bear five per cent interest 'from the first day of the seventh month after the freeing of the territory of the Republic of Ireland from Britain's military control and said Bond to be redeemable at par within one year thereafter. ${ }^{133}$ However, as Éamon de Valera, then attempting to secure popular and official American support for the nascent Irish republic, noted, the Bond Certificates were not issued 'on a purely financial

\footnotetext{
132 'Bond Certificate, Republic of Ireland', accessed via VUDL at http://digital.library.villanova.edu/Item/vudl:137444. Accessed 4 Mar. 2016.

${ }^{133}$ Fitzpatrick, Harry Boland, 143, 145.
} 
basis' to appeal to investors, but as a 'sentimental appeal.' ${ }^{134}$ Each investor should think of his purchase as a 'free gift of his money' and, as with Fenian bonds, small denominations were available for purchase. ${ }^{135}$ The Certificates were explicitly a form of 'special money': the market for them was built on sentiment and, as the organisers told it, the convictions of those 'Americans who love liberty and desire to see it triumph in Ireland.'136

Sentiment rhymed with good politics in two ways. First, as historian Francis M.

Carroll has argued, the process of issuing bonds was intended to engender legitimacy for the Irish republic as a nation-state. The issuance of bonds and their scheduled redemption conformed to norms that governed the way that recognised nation-states behaved. Second, De Valera also made a commitment to honour outstanding Fenian bonds. ${ }^{137}$ No-one was quite certain how many survived; the New York Times snarkily suggested that any that remained would owe their existence more to their use as 'shinplasters' or 'wallpaper' than to any longterm faith in Irish nationalism. ${ }^{138}$ The Provisional Government's Minister for Finance, Michael Collins, saw the virtue in stressing what he called 'continuity of responsibility': he believed that the redemption of Fenian bonds represented an act of justice to the past generations who had subscribed to the idea of an Irish republic virtually established. ${ }^{139}$ The precise nature of that redemption was contested as Collins and De Valera disagreed over the date from which interest ought to be paid on Fenian bonds but both accepted that bonds

\footnotetext{
${ }^{134}$ De Valera quoted in Fitzpatrick, Harry Boland, 143; and in Patricia Lavelle, James O'Mara: a Staunch SinnFeiner, 1873-1948 (Dublin, 1961), 148

135 De Valera quoted in Tim Pat Coogan, De Valera: Long Fellow, Long Shadow (London, 1993), 158; Lavelle, James O'Mara, 149. Historian Francis M. Carroll notes that 307,578 people purchased these Bond Certificates, and the majority invested $\$ 25$ or less. Carroll, Money for Ireland, 21-2.

136 'Sentiment' quotation from a conversation recounted by W. Bourke Cockran, quoted in Fitzpatrick, Harry Boland, 143. Zelizer, 'Social Meaning of Money', 348-353. Around \$5,800,000 was raised by two bond drives in the United States between 1919 and 1921. See Stephen Kelly, 'The Sinn Féin Millionaire: James O’Mara and the First American Bond-Certificate Drive, 1919-1921', New Hibernia Review, xv (2011), 76, fn5.

${ }^{137}$ De Valera quoted in Coogan, De Valera, 158; Carroll, Money for Ireland, 21. He did not differentiate between those issued by the O'Mahony and Roberts factions. His intention in honouring them was a product of concern for genealogy and legitimacy rather than finance, per se.

138 'Sinn Fein and Canada', New York Times, 8 Feb. 1920.

${ }^{139}$ Extract of Michael Collins to de Valera, 6 Oct. 1919 in TSCH/3/5749A, NAI.
} 
issued by either branch of the Fenian Brotherhood would function as proxy Bond Certificates, tying past generations of Irish nationalists in the United States into the contemporary effort to sustain the nascent republic.

In turn, the process of repaying those who had subscribed to the Bond Certificates was fraught and echoed the debates over legitimacy that led to civil war in Ireland between June 1922 and May 1923. Though the Irish Free State prevailed in that conflict, courts in the United States insisted in turning over money from bond sales to court-appointed receivers. ${ }^{140}$ They set about the time-intensive and costly process of identifying bondholders and administering payments to them. Ultimately, for every dollar subscribed in 1920-1921, fiftyeight cents was repaid. ${ }^{141}$ Shortly after becoming the head of the Irish government in spring 1932, de Valera, who had opposed the Free State's claim on money held in U.S. banks, announced that further reimbursement would be offered to American bondholders on the basis of moral - not legal - commitments that the Irish state had made to its early backers. ${ }^{142}$ In July 1933 the Dáil approved an Act to authorise redemption of the remaining American bonds, estimated to be worth between $\$ 5,040,000$ and $\$ 6,300,000$. This offered bondholders $\$ 1.25$ for every dollar subscribed, and set a deadline of 31 August 1934 for holders to file their claims. ${ }^{143}$ Between 1927 and 1937 the Irish government maintained a Loans Repayment Office at 117 Liberty Street, Manhattan, for redemption of the bonds issued between 1919 and 1921. Ultimately the office paid out just under \$2.5 million to American claimants. ${ }^{144}$

\footnotetext{
${ }^{140}$ Carroll, Money for Ireland, 44-5, 52-63.

141 Ibid., 78.

142 Ibid., 84-5.

143 The Dáil Eireann Loans and Funds (Amendment) Act, 1933. The deadline was extended to the end of June 1936 by the Dáil Eireann Loans and Funds (Amendment) Act, 1936. The text of both acts is available via the Irish Statute Book website at http://www.irishstatutebook.ie/eli/home.html Accessed 27 Jan. 2016.

${ }^{144}$ Carroll, Money for Ireland, 85-88.
} 
Those who failed to exchange their bonds, or who failed to redeem them within the specified period, found themselves out of luck, as a flurry of irate letters from Fenian bondholders after the formal establishment of the Republic of Ireland in 1949 testified. ${ }^{145}$ 'Surely the gentlemen now in power, do not wish to take all the credit for accomplishing the Irish freedom,' Elizabeth McLester needled. ${ }^{146}$ Irish politicians would undo the careful work of knitting together the generations should they 'forget entirely the work of their predecessors who laid the foundation for the work many of them sacrificing their lives in the effort. ${ }^{147}$ The most irritated supplicants went so far as to threaten litigation: for them, the bonds were not significant as special money but as a bankable financial instrument. ${ }^{148}$ For those who exchanged their Fenian bonds promptly the returns were reasonable if not spectacular: a $\$ 10$ 1866 bond, exchanged at par in 1920 , would yield $\$ 12.50$ in $1930 .^{149}$

The financial and political afterlives of the Fenian bond have been outlasted by another: the aesthetic. The bond behind the counter that could get Irish-Americans into trouble, noted above, suggested faith that the bond's aesthetic value outstripped its worth as a financial instrument. Here, Fenian bonds became an indicator, a marker in public space, of a shop or bar owner's support for the Irish Republic 'virtually established' - or perhaps a laconic joke for the clientele to enjoy over a drink. ${ }^{150}$ Michael Collins borrowed a Fenian bond with the intention of using it as a model for the bonds issued domestically in Ireland during the War of Independence, though ultimately the provisional government decided on

\footnotetext{
145 See various letters in TSCH/3/S5749A, NAI. The Department of the Taoiseach established a separate file for such letters in June 1949. Note of Roinn an Taoisigh, RA 175/38 in same.

${ }^{146}$ Elizabeth McLester to Éamon de Valera, 2 Aug. 1951, TSCH/3/S5749A, NAI.

147 ibid.

148 William F. Ahlbrecht to Sean T. O’Kelly, 23 May 1949, TSCH/3/S5749A, and same to Seán MacBride, 11 Mar. 1951, DFA/6/405/28, both NAI.

149 The value of an exchanged Fenian bond therefore outstripped the standard Consumer Price Index ( $\$ 10$ in 1866 is worth $\$ 10.90$ in 1930) though not the index for unskilled (or skilled) labourers' wages ( $\$ 29.20$ and $\$ 46.20$ respectively in 1930). Calculations via the Measuring Worth website at https://www.measuringworth.com/ Accessed 28 Jan. 2016.

${ }^{150}$ The IRB oath specified that members swear allegiance to an "Irish republic, virtually established." See Owen McGee, The IRB: the Irish Republican Broterhood, from the Land League to Sinn Féin (Dublin, 2007), 18.
} 
using a system of signed receipts instead. ${ }^{151}$ The man from whom he had borrowed it had taken the trouble to have it framed and 'placed within double plates of glass so that both sides are available for inspection.' ${ }^{152}$ And Fenian bonds retain their appeal to collectors. Despite their apparent ubiquity at mid-century - the American Irish Historical Society and the National Museum of Ireland both noted the frequency with which people offered them bonds for sale - those bonds, signed by O'Mahony and Scanlan, handled by saddlers, grocers and servant girls, now sell for twenty, forty, even sixty times their face value via online traders and high-end auction houses. ${ }^{153}$ Not such junk, after all.

Acknowledgments

The author would like to thank the convenors and attendees of the 2016 annual meeting of the Association of British American Nineteenth Century Historians; Robert Cook and attendees of the U.S. History seminar series at the University of Sussex; and Catherine Bateson, Sophie Cooper, Bobbie Nolan, Enda Delaney, and the folks at the Transnational Ireland workshop at the University of Edinburgh for invitations to discuss this project. Thanks also to Paul J. Kelly, the digital archivist at the Catholic University of America, and to Margot Finn, Adam Smith, Daniel Peart, and Claire Duddy for their thoughtful comments and constructive criticism.

\footnotetext{
${ }^{151}$ Paddy Hogan Meade to Ernest Blythe, 20 Jul. 1928, TSCH/3/S5749A, NAI; Margery Forester, Michael Collins: the Lost Leader (Dublin, 1989), 110.

${ }^{152}$ Meade to Blythe, 20 Jul. 1928, TSCH/3/S5749A, NAI.

${ }^{153}$ Executive Secretary of the American Irish Historical Society to John G. Ronan, 5 Dec. 1950, TSCH/3/S5749A, and Dr. Hayes McCoy's memorandum, 'U.S.A. "Fenian Bonds”, DFA/6/405/28, both NAI. A twenty dollar Scanlan bond, a ten dollar Scanlan bond, and a five dollar O’Mahony bond were sold by Whyte's auctioneers in March 2014 for $€ 380$ (ca. \$414), $€ 620$ (ca. \$675), and $€ 180$ (ca. \$196) respectively. Whyte’s online catalogue accessed at http://whytes.ie/14.asp?Auction=20140309\&Lot=1\&offset=104, accessed $15 \mathrm{Jan}$ 2016.
} 